Forschungszentrum Karlsruhe Technik und Umwelt

Wissenschaftliche Berichte

FZKA 6350

\title{
Solubility and Hydrolysis of Tetravalent Actinides
}

\author{
V. Neck, J. I. Kim
}

Institut für Nukleare Entsorgungstechnik 
Forschungszentrum Karlsruhe

Technik und Umwelt

Wissenschaftliche Berichte

FZKA 6350

Solubility and Hydrolysis of Tetravalent Actinides

V. Neck, J. I. Kim

Institut für Nukleare Entsorgungstechnik

Forschungszentrum Karlsruhe $\mathrm{GmbH}$, Karlsruhe 1999 
Als Manuskript gedruckt

Für diesen Bericht behalten wir uns alle Rechte vor

Forschungszentrum Karlsruhe GmbH Postfach 3640, 76021 Karlsruhe

Mitglied der Hermann von Helmholtz-Gemeinschaft Deutscher Forschungszentren (HGF)

ISSN 0947-8620 


\section{Summary}

The solubility and hydrolysis behaviour of Th(IV), U(IV), Np(IV) and Pu(IV) is critically reviewed. Based on a chemical model, which includes all mononuclear species $\mathrm{An}(\mathrm{OH})_{n}{ }^{4-n} \mathrm{up}$ to $\mathrm{n}=4$ and also polynuclear species, if necessary, the solubilities of amorphous An(IV) hydroxides or hydrous oxides are calculated as a function of $\mathrm{pH}$. The SIT is used for ionic strength corrections to evaluate the thermodynamic hydrolysis constants and solubility products at $\mathrm{I}=0$ and $25^{\circ} \mathrm{C}$.

At first, the hydrolysis constants from less ambiguous experiments are selected from the literature, e.g. from solvent extraction studies with $\mathrm{Pu}(\mathrm{IV})$ and $\mathrm{Np}(\mathrm{IV})$ trace concentrations, where the interference of colloid formation can be excluded, or from spectroscopic investigations on the initial hydrolysis of U(IV). Unknown formation constants of mononuclear hydrolysis species are estimated by applying semi-empirical models, correlating the known constants for tetravalent actinides with those of actinides of other oxidation states. Based on the known and estimated hydrolysis constants, the solubility products of $\mathrm{An}(\mathrm{OH})_{4}(\mathrm{am})$ or $\mathrm{AnO}_{2} \cdot \mathrm{xH}_{2} \mathrm{O}(\mathrm{am})$ are then evaluated from experimental solubility data available in the literature.

The solubilities of amorphous $\mathrm{Pu}(\mathrm{IV}), \mathrm{Np}(\mathrm{IV})$ and U(IV) precipitates in carbonate-free solutions of $\mathrm{pH} 1$ - 13 are well described with a model including solely mononuclear hydrolysis species. The neglected contributions of polynuclear or colloidal species do not exceed the range of uncertainty. In the case of Th(IV), no unambiguous thermodynamic constants could be evaluated. Accounting for the considerably higher solubilities of amorphous Th(IV) precipitates in the $\mathrm{pH}$ range $2-5$, a set of constants is evaluated, which includes the polynuclear species $\mathrm{Th}_{4}(\mathrm{OH})_{12}{ }^{4+}$ and $\mathrm{Th}_{6}(\mathrm{OH})_{15}{ }^{9+}$ proposed in potentiometric titration studies. However, recent investigations provided strong evidence for the formation of colloids under these conditions. 


\section{Löslichkeit und Hydrolyse von tetravalenten Actiniden}

\section{Zusammenfassung}

Der vorliegende Bericht beinhaltet eine Übersicht zum Kenntnistand bezüglich der Löslichkeit und Hydrolyse der tetravalenten Actiniden Th(IV), U(IV), $\mathrm{Np}(\mathrm{IV})$ and $\mathrm{Pu}(\mathrm{IV})$ und eine kritische Diskussion der publizierten thermodynamischen Daten. Die pH-abhängige Löslichkeit amorpher hydroxidischer oder oxidischer Festphasen wird beschrieben mit einem chemischen Modell, welches alle mononuklearen Hydrolysespezies $\mathrm{An}(\mathrm{OH})_{n}{ }^{4-n}$ mit $n=1-4$ und, sofern notwendig, auch polynukleare Spezies berücksichtigt. Unter Verwendung der SIT zur Berechnung von Aktivitätskoeffizienten wurden die thermodynamischen Hydrolysekonstanten und Löslichkeitsprodukte bei $\mathrm{I}=0$ und $25^{\circ} \mathrm{C}$ ermittelt.

In einem ersten Schritt wurden zuverlässige Hydrolysekonstanten aus der Literatur ausgewählt, z.B. aus Flüssig-flüssig-Extraktionsexperimenten mit Spurenkonzentrationen von $\mathrm{Pu}(\mathrm{IV})$ und $\mathrm{Np}$ (IV) oder aus spektroskopischen Untersuchungen zur ersten Hydrolysestufe von U(IV). Unbekannte Bildungskonstanten von An(IV)-Hydrolysespezies wurden abgeschätzt anhand semi-empirischer Methoden. Die Abschätzungen basieren auf den bekannten Daten für An(IV)-Spezies, sowie ihrer Korrelation mit Daten für Actinidspezies anderer Oxidationsstufen. Unter Verwendung der bekannten und abgeschätzten Hydrolysekonstanten wurden dann in einem zweiten Schritt die Löslichkeitsprodukte von $\mathrm{An}(\mathrm{OH})_{4}(\mathrm{am})$ bzw. $\mathrm{AnO}_{2} \cdot \mathrm{xH}_{2} \mathrm{O}(\mathrm{am})$ ermittelt, anhand experimenteller Löslichkeitsdaten aus der Literatur.

Die Löslichkeitsdaten für amorphe Festphasen von $\mathrm{Pu}(\mathrm{IV}), \mathrm{Np}(\mathrm{IV})$ und $\mathrm{U}(\mathrm{IV})$ in carbonatfreien Lösungen lassen sich im Bereich pH 1 - 13 thermodynamisch beschreiben anhand eines mononuklearen Hydrolyseschemas. Ein eventuell vorhandener, in diesem Ansatz vernachlässigter Beitrag von polynuklearen oder kolloidalen Spezies liegt im experimentellen Fehlerbereich. $\mathrm{Th}(\mathrm{OH})_{4}(\mathrm{am})$ bzw. $\mathrm{ThO}_{2} \cdot \mathrm{xH}_{2} \mathrm{O}(\mathrm{am})$ weisen im Bereich $\mathrm{pH} 2-5$ eine wesentlich höhere Löslichkeit auf. Sie wird beschrieben mit einem Satz von thermodynamischen Konstanten, der zusätzlich die polynuklearen Hydrolysespezies $\mathrm{Th}_{4}(\mathrm{OH})_{12}{ }^{4+}$ und $\operatorname{Th}_{6}(\mathrm{OH})_{15}{ }^{9+}$ enthält. Diese wurden in der Literatur abgeleitet aus potentiometrischen Titrationsexperimenten. In neueren Untersuchungen wurde jedoch nachgewiesen, daß unter diesen Bedingungen mit einer starken Kolloidbildung gerechnet werden muß. Für Th(IV) lassen sich daher keine eindeutigen bzw. zweifelsfreien thermodynamischen Konstanten angeben. 


\section{Contents}

1. Introduction 1

1.1. Definitions and terminology 2

1.2. Activity coefficients and ion interaction (SIT) coefficients 4

2. Hydrolysis 6

2.1. Discussion of literature data 6

2.2. Estimation of unknown constants 11

3. An(IV) hydroxides and oxides 14

3.1. Solubility products of crystalline $\mathrm{AnO}_{2}$ (cr) 14

3.2. Solubility products of amorphous hydroxides / hydrous oxides 15

3.2.1. Plutonium(IV) 16

3.2.2. Neptunium(IV) 20

3.2.3. Uranium(IV) 22

3.2.4. Thorium(IV) 27

4. Conclusions and summary of thermodynamic constants 31

5. References 33 


\section{Introduction}

Because of their high electric charge, tetravalent actinide ions have an inordinate tendency toward hydrolysis in aqueous solution. They undergo polynucleation or further to colloid formation. The solubilities of An(IV) hydroxides or oxides are low, and the possibility to investigate the aqueous speciation by spectroscopic methods is rather poor. Such underlying problems complicate the thermodynamic evaluation of the hydrolysis and solubility constants. The wide scattering in the published data prompts us to revisit the subject and to reevaluate critically the data and experimental results hitherto available in the literature.

In particular the solubility products reported for amorphous or microcrystalline $\mathrm{An}(\mathrm{OH})_{4}(\mathrm{am})$ or $\mathrm{AnO}_{2} \mathrm{xH}_{2} \mathrm{O}$ (s) show considerable discrepancies. Partly, the data do not refer to a welldefined unique solid phase, because the degree of crystallinity, particle size, the content of crystal water and hence the molar standard Gibbs free energy $\Delta_{\mathrm{r}} \mathrm{G}^{\circ}$ depend on the preparation method, pretreatment, alteration and temperature [82RAI/RYA, 83STR/RAI, 84GRE/LIE, 92GRE/FUG]. Furthermore, the $\mathrm{An}^{4+}$ ions hydrolyse even at low $\mathrm{pH}$, and there are no solubility data with $\mathrm{An}^{4+}$ as the predominant equilibrium aqueous species. Therefore, the hydrolysis constants and solubility products of An(IV) oxides or hydroxides cannot be evaluated independently from solubility data. The solubility products evaluated from experimental solubility data strongly depend on the hydrolysis constants applied to calculate the $\mathrm{An}^{4+}$ from the total $\mathrm{An}(\mathrm{IV})$ concentration. The $\mathrm{pH}$-dependent solubility of the hydrous oxides is often described by very simple chemical models, neglecting most of the hydrolysis species, e.g. polynuclear species, $\mathrm{An}(\mathrm{OH})_{2}{ }^{2+}, \mathrm{An}(\mathrm{OH})_{3}{ }^{+}$, and partly even $\mathrm{An}(\mathrm{OH})^{3+}[84 \mathrm{RAI}$, 91FEL/RAI, 97RAI/FEL, 95YAJ/KAW]. Hence, the calculated $\mathrm{An}^{4+}$ concentrations and solubility products are considerably overestimated. Such models (implying incorrect thermodynamic data) are useful for the prediction of solubilities. However, they do not reflect the aqueous speciation.

In order to avoid such ambiguities, the present calculations are based on a model, which includes a complete set of mononuclear species $\mathrm{An}(\mathrm{OH})_{\mathrm{n}}{ }^{4-n}$ up to $n=4$. If necessary, polynuclear species are included as well. In a first step, the known hydrolysis constants are selected from the literature, and unknown hydrolysis constants are estimated by applying semi-empirical models and correlations. In a second step, these hydrolysis constants are used to calculate the aqueous speciation at given $\mathrm{pH}$, and the solubility products of $\mathrm{AnO}_{2} \mathrm{xH}_{2} \mathrm{O}(\mathrm{s})$ or $\mathrm{An}(\mathrm{OH})_{4}(\mathrm{am})$ are evaluated from available experimental solubility data. The calculations are restricted to solutions of ionic strength $\mathrm{I} \leq 1 \mathrm{~mol} / \mathrm{l}$. At chloride solutions below $1 \mathrm{~mol} / \mathrm{l}$, the complexation with of $\mathrm{An}^{4+}$ with chloride ions is negligible. 


\subsection{Definitions and terminology}

The formation of a hydroxo complex $\mathrm{An}_{\mathrm{x}}(\mathrm{OH})_{\mathrm{y}}{ }^{4 \mathrm{x}-\mathrm{y}}=(\mathrm{xy})$ is described according to the reaction

$$
x \mathrm{An}^{4+}+\mathrm{y} \mathrm{OH}^{-} \Leftrightarrow \mathrm{An}_{\mathrm{x}}(\mathrm{OH})_{\mathrm{y}}^{4 \mathrm{x}-\mathrm{y}}
$$

with

$$
\beta_{x y}^{\prime}=\left[\mathrm{An}_{\mathrm{x}}(\mathrm{OH})_{\mathrm{y}}^{4 \mathrm{x}-\mathrm{y}}\right] /\left[\mathrm{An}^{4+}\right]^{\mathrm{x}}\left[\mathrm{OH}^{-}\right]^{\mathrm{y}}
$$

and

$$
\begin{aligned}
\beta_{x y}^{\circ} & =\left(\mathrm{An}_{x}(\mathrm{OH})_{y}{ }^{4 x-y}\right) /\left(\mathrm{An}^{4+}\right)^{\mathrm{x}}\left(\mathrm{OH}^{-}\right)^{y} \\
& =\beta^{y}{ }_{x y}\left(\gamma_{\mathrm{An}_{\mathrm{x}}(\mathrm{OH})_{\mathrm{y}}}\right)\left(\gamma_{\mathrm{An}}\right)^{-\mathrm{x}}\left(\gamma_{\mathrm{OH}}\right)^{-\mathrm{y}}
\end{aligned}
$$

where $\beta^{\prime}{ }_{x y}=$ formation constant of species (xy) in a given medium

$\beta_{x y}^{\circ}=$ thermodynamic formation constant of species (xy) at infinite dilution $(I=0)$

[ ] = concentration (molar or molal)

()$=$ activity

$\gamma_{i}=$ activity coefficient of species $i$

$\mathrm{a}_{\mathrm{w}}=$ activity of water

In the literature hydrolysis reactions are often either written as reaction with water molecules

$$
x \mathrm{An}^{4+}+\mathrm{y} \mathrm{H} \mathrm{H}_{2} \mathrm{O} \Leftrightarrow \mathrm{An}_{\mathrm{x}}(\mathrm{OH})_{\mathrm{y}}^{4 \mathrm{x}-\mathrm{y}}+\mathrm{y} \mathrm{H}^{+}
$$

with

$$
\mathrm{K}_{\mathrm{xy}}^{\prime}=\left[\mathrm{An}_{\mathrm{x}}(\mathrm{OH})_{\mathrm{y}}{ }^{(4 \mathrm{x}-\mathrm{y})}\right]\left[\mathrm{H}^{+}\right]^{\mathrm{y}} /\left[\mathrm{An}^{4+}\right]^{\mathrm{x}}
$$

and

$$
\begin{aligned}
K^{\circ}{ }_{x y} & =\left(\operatorname{An}_{x}(O H)_{y}{ }^{4 x-y}\right)\left(H^{+}\right)^{y} /\left(A^{4+}\right)^{x}\left(a_{w}\right)^{y} \\
& =K_{x y}^{\prime}\left(\gamma_{A n_{x}}(O H)_{y}\right)\left(\gamma_{H}\right)^{y}\left(\gamma_{A n}\right)^{-x}\left(a_{w}\right)^{-y}
\end{aligned}
$$

where $\mathrm{K}^{\prime}{ }_{\mathrm{xy}}=$ hydrolysis constant in a given medium

$\mathrm{K}^{\mathrm{o}}{ }_{\mathrm{xy}}=$ thermodynamic hydrolysis constant at infinite dilution $(\mathrm{I}=0)$

In some cases, the stepwise hydrolysis constants ${ }^{*} \mathrm{~K}_{n}{ }_{n}$ for mononuclear species $\mathrm{An}(\mathrm{OH})_{n}{ }^{4-\mathrm{n}}$ are given:

$$
\mathrm{An}(\mathrm{OH})_{\mathrm{n}-1}{ }^{4-(\mathrm{n}-1)}+\mathrm{H}_{2} \mathrm{O} \Leftrightarrow \mathrm{An}(\mathrm{OH})_{n}^{4-n}+\mathrm{H}^{+}
$$

with

$$
{ }^{*} \mathrm{~K}_{\mathrm{n}}=\left[\mathrm{An}(\mathrm{OH})_{\mathrm{n}}^{4-\mathrm{n}}\right]\left[\mathrm{H}^{+}\right] /\left[\mathrm{An}(\mathrm{OH})_{\mathrm{n}-1}{ }^{4-(\mathrm{n}-1)}\right]
$$

The hydrolysis constants $\log \mathrm{K}^{\prime}{ }_{\mathrm{xy}}$ are related to the formation constants $\log \beta_{\mathrm{xy}}^{\prime}$ by the ion 
product of water $\left(\log \mathrm{K}^{\prime}{ }_{\mathrm{w}}\right)$ :

$$
\log \mathrm{K}_{\mathrm{xy}}=\log \beta_{\mathrm{xy}}+\mathrm{y} \log \mathrm{K}_{\mathrm{w}}
$$

with

$$
\begin{aligned}
& \mathrm{K}^{\prime}{ }_{\mathrm{w}}=\left[\mathrm{H}^{+}\right]\left[\mathrm{OH}^{-}\right] \\
& \mathrm{K}^{\circ}{ }_{\mathrm{w}}=\left(\mathrm{H}^{+}\right)\left(\mathrm{OH}^{-}\right)=\mathrm{K}^{\prime}{ }_{\mathrm{w}}\left(\gamma_{\mathrm{H}}\right)\left(\gamma_{\mathrm{OH}}\right)\left(\mathrm{a}_{\mathrm{w}}\right)^{-1}
\end{aligned}
$$

and $\left.\log \mathrm{K}^{\circ}{ }_{\mathrm{w}}=-14.00 \pm 0.01[92 \mathrm{GRE} / \mathrm{FUG}]\right)$.

Throughout the present report, the solubility products of amorphous An(IV) precipitates, $\mathrm{An}(\mathrm{OH})_{4}(\mathrm{am})$ or $\mathrm{AnO}_{2} \times \mathrm{H}_{2} \mathrm{O}(\mathrm{s})$, and crystalline dioxides $\mathrm{AnO}_{2}(\mathrm{cr})$ are defined according to the dissolution reactions

$$
\mathrm{An}(\mathrm{OH})_{4}(\mathrm{am})<\mathrm{An}^{4+}+4 \mathrm{OH}^{-}
$$

or

$$
\mathrm{AnO}_{2} \times \mathrm{H}_{2} \mathrm{O}(\mathrm{am})+(2-\mathrm{x}) \mathrm{H}_{2} \mathrm{O} \Leftrightarrow \mathrm{An}^{4+}+4 \mathrm{OH}^{-}
$$

and

$$
\mathrm{AnO}_{2}(\mathrm{cr})+2 \mathrm{H}_{2} \mathrm{O} \Leftrightarrow \mathrm{An}^{4+}+4 \mathrm{OH}^{-}
$$

For better comparison the same definitions of $\mathrm{K}_{\text {sp }}$ are used for hydroxides and oxides:

$$
\mathrm{K}_{\mathrm{sp}}^{\prime}=\left[\mathrm{An}^{4+}\right]\left[\mathrm{OH}^{-}\right]^{4}
$$

with

$$
\begin{aligned}
\mathrm{K}_{\text {sp }}^{\circ} & =\left(\mathrm{An}^{4+}\right)\left(\mathrm{OH}^{-}\right)^{4} \\
& =\mathrm{K}_{\mathrm{xy}}^{\prime}\left(\gamma_{\mathrm{An}}\right)\left(\gamma_{\mathrm{OH}}\right)^{4} \quad\left(\text { for } \mathrm{An}(\mathrm{OH})_{4}(\mathrm{am})\right)
\end{aligned}
$$

and

$$
\begin{aligned}
\mathrm{K}^{\circ}{ }_{\mathrm{sp}} & =\left(\mathrm{An}^{4+}\right)\left(\mathrm{OH}^{-}\right)^{4}\left(\mathrm{a}_{\mathrm{w}}\right)^{(\mathrm{x}-2)} \\
& =\mathrm{K}^{\prime}{ }_{\mathrm{xy}}\left(\gamma_{\mathrm{An}}\right)\left(\gamma_{\mathrm{OH}}\right)^{4}\left(\mathrm{a}_{\mathrm{w}}\right)^{(\mathrm{x}-2)} \quad\left(\text { for } \mathrm{AnO}_{2} \cdot \mathrm{x} \mathrm{H}_{2} \mathrm{O}(\mathrm{s})\right)
\end{aligned}
$$

respectively. The number of crystal water molecules is usually not known exactly. However, in solutions of low ionic strength, the effect of the water activity is negligible $\left(\log a_{w} \approx 0\right)$.

The $\mathrm{pH}$ value is defined as the negative decadic logarithm of the $\mathrm{H}^{+}$activity:

$$
\mathrm{pH}=-\log \left[\mathrm{H}^{+}\right]-\log \gamma_{\mathrm{H}}
$$

In experimental studies at $\mathrm{I}=1 \mathrm{~mol} / 1$ [86LIE/KIM, 89KIM/KAN, 99GRA/MÜL], where $\mathrm{pH}$ was measured with ROSS electrodes calibrated against standard $\mathrm{pH}$ buffer solutions, the given values $\mathrm{pH}_{\mathrm{obs}}$ are converted into $\log \left[\mathrm{H}^{+}\right]$using the experimental relation $\log \left[\mathrm{H}^{+}\right]=-\mathrm{pH}_{\mathrm{obs}}-\mathrm{A}$ with $\mathrm{A}=0.23$ in $1 \mathrm{M} \mathrm{NaClO}_{4}$ [96FAN/NEC] and 0.14 in $1 \mathrm{M} \mathrm{NaCl}$ [97RAI/FEL]. 


\subsection{Activity coefficients and ion interaction (SIT) coefficients}

In the present report, the specific ion interaction theory (SIT) [80CIA, 92GRE/FUG] is applied for the calculation of activity coefficients. In contrast to the simple SIT equations, the more elaborated Pitzer approach [91PIT] is applicable from dilute solutions to concentrated multicomponent systems of the seawater salt system [80HAR/WEA, 84HAR/MØL], whereas the SIT can become inaccurate at ionic strengths above $3 \mathrm{~mol} / \mathrm{kg} \mathrm{H}_{2} \mathrm{O}$. However, the hitherto available database on interaction parameters for $\mathrm{An}^{4+}$ ions and their hydrolysis species is not sufficient, i.e. missing interaction coefficients have to be estimated. The SIT is prefered, because somewhat uncertain estimates for SIT coefficients have no significant effect on the calculation of activity coefficients at $I \leq 0.1 \mathrm{~mol} / \mathrm{kg}$, whereas the estimates for Pitzer coefficients $\beta^{(1)}$ have a considerable effect as well at low ionic strength. As the SIT coefficients become important with increasing ionic strength, the present calculations are restricted to experimental data at $I \leq 1 \mathrm{~mol} / \mathrm{kg}$.

According to the SIT, activity coefficients $\gamma_{i}$ are given by

$$
\log \gamma_{i}=-z_{i}^{2} \mathrm{D}+\Sigma \varepsilon_{i j} m_{j}
$$

where $z_{i}$ is the charge of ion $i, m_{j}\left(m o l / k g ~ \mathrm{H}_{2} \mathrm{O}\right)$ the molal concentration of ion $\mathrm{j}, \mathrm{D}$ is the Debye-Hückel term at $25^{\circ} \mathrm{C}: \mathrm{D}=0.509 \sqrt{\mathrm{I}} /(1+\mathrm{Bå} \sqrt{\mathrm{I}})$, with $\mathrm{Ba}=1.5$. I is the molal ionic strength, and $\varepsilon_{\mathrm{ij}}$ is the interaction parameter for a pair of oppositely charged ions.

The medium specific equilibrium constant $\mathrm{K}^{\prime}$ is related to $\mathrm{K}^{\circ}$ at $\mathrm{I}=0$ by

$$
\log \mathrm{K}^{\prime}=\log \mathrm{K}^{\circ}+\Delta \mathrm{z}^{2} \mathrm{D}-\Delta \varepsilon \cdot \mathrm{I}
$$

with

and

$$
\Delta \mathrm{z}^{2}=\Sigma \mathrm{z}_{\mathrm{i}}^{2} \text { (products) }-\Sigma \mathrm{z}_{\mathrm{i}}^{2} \text { (educts) }
$$

$$
\Delta \varepsilon=\Sigma \varepsilon_{\mathrm{ij}} \text { (products) }-\Sigma \varepsilon_{\mathrm{ij}} \text { (educts). }
$$

The ion interaction coefficients $\varepsilon_{\mathrm{ij}}$ used in the present study are summarized in Table 1.1. As far as available, they are taken from NEA-TDB [92GRE/FUG, 95SIL/BID]. Unknown interaction parameters are estimated according to known analogies and systematics.

The activity coefficient of an aqueous species depends on its interactions with the ions in solution and $\mathrm{H}_{2} \mathrm{O}$ solvent molecules. Hence the interaction parameters for the calculation of activity coefficients primarily depend on the ionic charge and the interaction distances. In general, for aquo ions or complex species of equal charge and symmetry, small differences in their ionic radii only slightly affect the activity coefficients [91PIT]. As a consequence, ion 
interaction (SIT or Pitzer) parameters can be set equal for $\mathrm{Nd}^{3+}, \mathrm{Am}^{3+}$ and $\mathrm{Cm}^{3+}$ [90FEL/RAI, 97KÖN/FAN], $\mathrm{NpO}_{2}{ }^{+}$and $\mathrm{AmO}_{2}{ }^{+}$[96RUN/NEU], and $\mathrm{UO}_{2}{ }^{2+}$ and $\mathrm{PuO}_{2}{ }^{2+}$ [97PAS/CZE]. In the case of tetravalent actinide aquo ions $\mathrm{An}^{4+}(\mathrm{An}=\mathrm{Th}, \mathrm{U}, \mathrm{Np}, \mathrm{Pu})$, the high charge and the somewhat larger differences in ionic radii lead to certain differences in the activity coefficients (c.f. $\varepsilon_{i j}$ values from [92GRE/FUG, 95SIL/BID] shown in Table 1.1). In the case of complex species, medium ions and solvent molecules interact primarily with the surrounding ligands. The size of the central actinide ion is not of decisive importance. Therefore, equal interaction parameters can be used for the calculation of trace activity coefficients for analogous complexes of Th(IV), U(IV), $\mathrm{Np}(\mathrm{IV})$ and $\mathrm{Pu}(\mathrm{IV})$.

Table 1.1 Ion interaction (SIT) coefficients at $25^{\circ} \mathrm{C}$ used in the present report (from the NEA-TDB [92GRE/FUG, 95SIL/BID], except otherwise stated)

\begin{tabular}{|c|c|c|c|c|c|}
\hline $\mathrm{i}$ & $\mathrm{j}$ & $\varepsilon_{i j}$ & & & \\
\hline $\mathrm{H}^{+}$ & $\mathrm{ClO}_{4}^{-}$ & $0.14 \pm 0.02$ & & & \\
\hline $\mathrm{H}^{+}$ & $\mathrm{Cl}^{-}$ & $0.12 \pm 0.01$ & & & \\
\hline \multirow[t]{2}{*}{$\mathrm{OH}^{-}$} & $\mathrm{Na}^{+}$ & $0.04 \pm 0.01$ & & & \\
\hline & & $\operatorname{Th}(\mathrm{IV})$ & $\mathrm{U}(\mathrm{IV})$ & $\mathrm{Np}(\mathrm{IV})$ & $\mathrm{Pu}(\mathrm{IV})$ \\
\hline $\mathrm{An}^{4+}$ & $\mathrm{ClO}_{4}^{-}$ & $0.67 \pm 0.1^{a)}$ & $0.76 \pm 0.06$ & $0.82 \pm 0.05$ & $0.83 \pm 0.1^{b)}$ \\
\hline $\mathrm{An}(\mathrm{OH})^{3+}$ & $\mathrm{ClO}_{4}^{-}$ & $0.45 \pm 0.1^{a)}$ & $0.48 \pm 0.08$ & $0.5 \pm 0.1^{\mathrm{a})}$ & $0.5 \pm 0.1^{\mathrm{a})}$ \\
\hline $\mathrm{An}(\mathrm{OH})_{2}{ }^{2+}$ & $\mathrm{ClO}_{4}^{-}$ & $0.3 \pm 0.1^{a)}$ & $0.3 \pm 0.1^{a)}$ & $0.3 \pm 0.1^{a)}$ & $0.3 \pm 0.1^{a)}$ \\
\hline $\mathrm{An}(\mathrm{OH})_{3}{ }^{+}$ & $\mathrm{ClO}_{4}^{-}$ & $0.15 \pm 0.1^{a)}$ & $0.15 \pm 0.1^{\mathrm{a})}$ & $0.15 \pm 0.1^{a)}$ & $0.15 \pm 0.1^{a)}$ \\
\hline $\mathrm{An}(\mathrm{OH})_{4}^{\circ}$ & $\mathrm{ClO}_{4}^{-}$ & 0 & 0 & 0 & 0 \\
\hline $\mathrm{An}^{4+}$ & $\mathrm{Cl}^{-}$ & $0.25 \pm 0.03$ & $0.36 \pm 0.1^{a)}$ & $0.4 \pm 0.1^{a)}$ & $0.4 \pm 0.1^{\text {a) }}$ \\
\hline $\mathrm{An}(\mathrm{OH})^{3+}$ & $\mathrm{Cl}^{-}$ & $0.2 \pm 0.1^{a)}$ & $0.2 \pm 0.1^{\mathrm{a})}$ & $0.2 \pm 0.1^{a)}$ & $0.2 \pm 0.1^{a)}$ \\
\hline $\mathrm{An}(\mathrm{OH})_{2}{ }^{2+}$ & $\mathrm{Cl}^{-}$ & $0.1 \pm 0.1^{a)}$ & $0.1 \pm 0.1^{a)}$ & $0.1 \pm 0.1^{a)}$ & $0.1 \pm 0.1^{a)}$ \\
\hline $\mathrm{An}(\mathrm{OH})_{3}{ }^{+}$ & $\mathrm{Cl}^{-}$ & $0.05 \pm 0.1^{\mathrm{a})}$ & $0.05 \pm 0.1^{a)}$ & $0.05 \pm 0.1^{\mathrm{a})}$ & $0.05 \pm 0.1^{\mathrm{a})}$ \\
\hline $\mathrm{An}(\mathrm{OH})_{4}^{\circ}$ & $\mathrm{Cl}^{-}$ & 0 & 0 & 0 & 0 \\
\hline $\mathrm{An}(\mathrm{OH})_{4}^{\circ}$ & $\mathrm{Na}^{+}$ & 0 & 0 & 0 & 0 \\
\hline $\mathrm{An}(\mathrm{OH})_{5}^{-}$ & $\mathrm{Na}^{+}$ & $-0.05 \pm 0.1^{a)}$ & $-0.05 \pm 0.1^{\text {a) }}$ & $-0.05 \pm 0.1^{a)}$ & $-0.05 \pm 0.1^{a)}$ \\
\hline
\end{tabular}

a) Estimated according to the analogies and systematics outlined in the text.

b) Capdevila and Vitorge [98CAP/VIT] report two independently determined values: $0.85 \pm 0.20$ and $0.82 \pm 0.07$. The value of $1.03 \pm 0.05$ (from Vitorge et al.) given in the NEA-TDB [95SIL/BID] must be revised. 


\section{Hydrolysis}

\subsection{Discussion of literature data}

\section{Thorium (IV)}

A large number of investigations are reported on the hydrolysis behaviour of $T h(I V)$, mainly based on potentiometric titration studies in the range $\mathrm{pH}=2.5-4$ and total thorium concentrations ranging from $10^{-4}-10^{-2} \mathrm{~mol} / \mathrm{l}$. Reviews are given in [76BAE/MES, $83 \mathrm{BRO} / \mathrm{ELL}]$. In general, the potentiometric titration curves were interpreted assuming hydrolysis negligible at $\mathrm{pH}<2.5$, and proposing a suitable set of $\operatorname{species}^{\mathrm{T}} \mathrm{Th}_{\mathrm{x}}(\mathrm{OH})_{\mathrm{y}}{ }^{4 \mathrm{x}-\mathrm{y}}=(\mathrm{x}, \mathrm{y})$

$$
\begin{aligned}
& \text { e.g. } \quad(x, y)=(1,1),(1,2),(2,2),(4,8),(6,15)[65 \mathrm{BAE} / \mathrm{MEY}, 76 \mathrm{BAE} / \mathrm{MES}] \\
& (\mathrm{x}, \mathrm{y})=(1,1),(4,12) \text { and }(6,15)[83 \mathrm{BRO} / \mathrm{ELL}] . \\
& (\mathrm{x}, \mathrm{y})=(1,1),(1,4),(2,2),(2,3),(4,8),(4,12),(6,14),(6,16)[91 \mathrm{GRE} / \mathrm{LAG}] .
\end{aligned}
$$

Other authors postulated also the formation of the species $(2,5),(3,1),(3,3),(3,6)$ and $(10,25)$. The proposed polynuclear species are the result of best fitting procedures. They are not ascertained by spectroscopic or other methods. Moreover it was shown by Laser-induced breakdown detection (LIBD) [96KNO, 99BUN] that, under the conditions usually applied in potentiometric titration studies $\left([\mathrm{Th}]=10^{-4}-10^{-2} \mathrm{~mol} / \mathrm{l}, \mathrm{pH}=2.5-4\right)$, considerable amounts of Th(IV) colloids are formed. The average diameter of the detected colloids was found to be 10 - $20 \mathrm{~nm}$, i.e. one colloid contains more than $1000 \mathrm{ThO}_{2}$ or $\mathrm{Th}(\mathrm{OH})_{4}$ units. (Smaller colloidal particles with a diameter of $1-5 \mathrm{~nm}$, which could be present as well, cannot be detected by LIBD). Accordingly it appears questionable, whether the potentiometric titration curves are actually caused by well-defined polynuclear solution species or by colloids of varying composition, formed as a prestep of precipitation in oversaturated solutions (c.f. section 3.2.4). For these reasons it is not surprising that potentiometric studies performed by different authors, in different media, at different ionic strength and temperature or at different total thorium concentrations were interpreted with different sets of species and hydrolysis constants. Hence, the published data cannot be compared directly, and it is impossible to decide, which set of polynuclear species and hydrolysis constants is the most realistic one. The data sets evaluated by Baes and Mesmer [76BAE/MES] and Brown et al. [83BRO/ELL] are shown in Table 2.1.

Within most of the potentiometric titration studies, mononuclear species were found to be of minor importance or even negligible compared to the polynuclear species. The hydrolysis constants selected in the review of Baes and Mesmer [76BAE/MES] for the species 
$\mathrm{Th}(\mathrm{OH})^{3+}$ and $\mathrm{Th}(\mathrm{OH})_{2}{ }^{2+}$ are frequently accepted in thermodynamic data bases:

$$
\begin{array}{ll}
\log \mathrm{K}_{11}^{\circ}=-3.2 \pm 0.2 & \log \beta^{\circ}{ }_{11}=10.8 \pm 0.2 \\
\log \mathrm{K}^{\circ}{ }_{12}=-6.9 \pm 0.2 & \log \beta^{\circ}{ }_{12}=21.1 \pm 0.2
\end{array}
$$

They are orders of magnitude smaller than the corresponding constants for other $\mathrm{An}^{4+}$ ions. Brown et al. [83BRO/ELL] found more significant contributions of the species $\mathrm{Th}(\mathrm{OH})^{3+}$ and evaluated a somewhat greater constant of $\log \mathrm{K}_{11}^{\prime}=-2.98 \pm 0.01$ in $0.1 \mathrm{M} \mathrm{KNO}_{3}$, which can be converted to $\mathrm{I}=0$ with the SIT equation:

$$
\log \mathrm{K}_{11}^{\circ}=-2.3 \quad \log \beta^{\circ}{ }_{11}=11.7
$$

The same value is obtained from $\log \mathrm{K}_{11}^{\prime}=-3.28$ in $0.5 \mathrm{M} \mathrm{KNO}_{3}$, which has been determined in [84NAK/ZIM] by solvent extraction with TBP at $25^{\circ} \mathrm{C}$. The hydrolysis constants $\log \mathrm{K}^{\circ}{ }_{13}$ and $\log \mathrm{K}^{\circ}{ }_{14}$ given by Baes and Mesmer [76BAE/MES] are based on solubility data from [64NAB/KUD], which are conflicting with solubility data published later by other authors

\begin{tabular}{|c|c|c|c|c|c|}
\hline Species & $\log K_{x y}^{\prime}{ }^{a)}$ & $\left.\log K_{x y}^{o}{ }^{a}\right)$ & $\left.\log \beta_{x y}^{\prime} b\right)$ & $\left.\log \beta_{x y}^{o} b\right)$ & Ref. \\
\hline $\mathrm{Th}(\mathrm{OH})^{3+}$ & & $-3.20 \pm 0.2$ & & $10.8 \pm 0.2$ & [76BAE/MES] \\
\hline $\mathrm{Th}(\mathrm{OH})_{2}{ }^{2+}$ & & $-6.93 \pm 0.2$ & & $21.1 \pm 0.2$ & \\
\hline $\mathrm{Th}(\mathrm{OH})_{3}{ }^{+}$ & & $<-11.7$ & & $<30.3$ & \\
\hline $\mathrm{Th}(\mathrm{OH})_{4}(\mathrm{aq})$ & & $-15.9 \pm 0.3$ & & $40.1 \pm 0.3$ & \\
\hline $\mathrm{Th}_{2}(\mathrm{OH})_{2}{ }^{6+}$ & & $-6.14 \pm 0.06$ & & $21.9 \pm 0.1$ & \\
\hline $\mathrm{Th}_{4}(\mathrm{OH})_{8}{ }^{8+}$ & & $-21.1 \pm 0.1$ & & $90.9 \pm 0.1$ & \\
\hline $\mathrm{Th}_{6}(\mathrm{OH})_{15}{ }^{9+}$ & & $-36.76 \pm 0.06$ & & $173.2 \pm 0.1$ & \\
\hline $\mathrm{Th}(\mathrm{OH})^{3+}$ & $-2.98 \pm 0.01^{c)}$ & -2.3 & $10.8^{\mathrm{c})}$ & 11.7 & [83BRO/ELL] \\
\hline $\mathrm{Th}_{4}(\mathrm{OH})_{12}{ }^{4+}$ & $-30.55 \pm 0.03^{c)}$ & & $135.0^{\mathrm{c})}$ & & \\
\hline $\mathrm{Th}_{6}(\mathrm{OH})_{15}{ }^{9+}$ & $-34.42 \pm 0.03^{c)}$ & & $172.5^{\mathrm{c})}$ & & \\
\hline
\end{tabular}
(c.f. section 3.2.4).

Table 2.1. Formation constants of Th(IV) hydrolysis species at $25^{\circ} \mathrm{C}$

a) referring to the reaction: $\mathrm{x} \mathrm{An}^{4+}+\mathrm{y} \mathrm{H}_{2} \mathrm{O} \Leftrightarrow \mathrm{An}_{\mathrm{x}}(\mathrm{OH})_{\mathrm{y}}{ }^{4 \mathrm{x}-\mathrm{y}}+\mathrm{yH^{+ }}$

b) referring to the reaction: $\mathrm{xAn}^{4+}+\mathrm{yOH}^{-} \Leftrightarrow \mathrm{An}_{\mathrm{x}}(\mathrm{OH})_{\mathrm{y}}{ }^{4 \mathrm{x}-\mathrm{y}}$

c) in $0.1 \mathrm{M} \mathrm{KNO}_{3}$ 


\section{$\operatorname{Uranium}(I V)$}

The formation of $\mathrm{U}(\mathrm{OH})^{3+}$ has been investigated by numerous authors in different media, preferentially by spectroscopy in the range $\mathrm{pH}=0-2$. The thermodynamic constants selected in the NEA and IAEA reviews $\left(\log \mathrm{K}^{\circ}{ }_{11}=-0.54 \pm 0.06[92 \mathrm{GRE} / \mathrm{FUG}]\right.$ and $-0.34 \pm$ 0.20 [92FUG/KHO]) are in reasonable agreement, and the mean value is given by:

$$
\log \mathrm{K}_{11}^{\circ}=-0.4 \pm 0.2 \quad \log \beta_{11}^{\circ}=13.6 \pm 0.2
$$

For other mononuclear hydrolysis species of U(IV) no unambigious data are available [92GRE/FUG]. Attempts to calculate $\log \mathrm{K}_{12}, \log \mathrm{K}_{13}$ or $\log \mathrm{K}_{14}$ from solubility data are connected with the uncertainty concerning the solid phase and with the redundance of the hydrolysis constants and solubility product. A potentiometric titration study in $3 \mathrm{M} \mathrm{NaClO}_{4}$ $[56 \mathrm{HIE}]$ was interpreted with the formation of $\mathrm{U}_{6}(\mathrm{OH})_{15}{ }^{9+}[76 \mathrm{BAE} / \mathrm{MES}, 92 \mathrm{GRE} / \mathrm{FUG}]$ and $\log \mathrm{K}_{6,15}^{\prime}=-16.9 \pm 0.6$.

\section{Neptunium(IV) and Plutonium(IV)}

Spectroscopic studies on the initial mononuclear hydrolysis are reported for both, $\mathrm{Np}(\mathrm{IV})$ and $\mathrm{Pu}(\mathrm{IV})$ (Table 2.2). However, the concentrations used in these studies $\left([\mathrm{Np}(\mathrm{IV})]=1 \cdot 10^{-3}\right.$ $\left.7 \cdot 10^{-3} \mathrm{M},[\mathrm{Pu}(\mathrm{IV})]=7 \cdot 10^{-4}-2 \cdot 10^{-3} \mathrm{M}\right)$ exceed the solubility limit of the $\mathrm{Np}(\mathrm{IV})$ and $\mathrm{Pu}(\mathrm{IV})$ hydrous oxides at $\mathrm{pH}=1-2$ (c.f. Figs. 3.1 and 3.2 in section 3.2). The same holds for studies on the $\mathrm{Pu}(\mathrm{III}) / \mathrm{Pu}(\mathrm{IV})$ redox couples [51RAB/LEM, 57RAB]. As a consequence, colloid formation, which can avoid visible precipitation, has to be expected in these studies, leading to misinterpretations and erroneous data. Solely the stepwise hydrolysis constants reported by Guillaumont et al. [72MET/GUI, 77DUP/GUI] were determined in undersaturated solutions, by solvent extraction studies using Np-239 and $\mathrm{Pu}-238$ trace concentrations at $\mathrm{I}=1.0 \mathrm{~mol} / \mathrm{l}$ $\left(\mathrm{HClO}_{4} / \mathrm{LiClO}_{4}\right)$ :

$\mathrm{Pu}(\mathrm{IV}): \log { }^{*} \mathrm{~K}_{1}^{\prime}=-0.45, \log { }^{*} \mathrm{~K}_{2}{ }_{2}=-0.75, \log { }^{*} \mathrm{~K}_{3}{ }_{3}=-3.3, \log { }^{*} \mathrm{~K}_{4}{ }_{4}=-6.3 \quad[72 \mathrm{MET} / \mathrm{GUI}]$ $\mathrm{Np}(\mathrm{IV}): \log *^{*}{ }^{\prime}{ }_{1}=-0.5, \log *^{*} \mathrm{~K}_{2}=-1.0[77 \mathrm{DUP} / \mathrm{GUI}]$

These constants are considered to be the most reliable among the published data for $\mathrm{Np}$ (IV) and $\mathrm{Pu}(\mathrm{IV})$. They are converted to $\mathrm{I}=0$ with the ion interaction SIT coefficients discussed in section 1.2 (Table 1.1). As no experimental uncertainties are given in [72MET/GUI, 77DUP/GUI], they are estimated to be about $0.2 \log$ units for each hydrolysis step. 
Table 2.2. Formation constants of $\mathrm{Np}(\mathrm{IV})$ and $\mathrm{Pu}(\mathrm{IV})$ hydrolysis species at $20-25^{\circ} \mathrm{C}$

\begin{tabular}{|c|c|c|c|c|c|}
\hline Medium / Species & $\log K_{1 y}^{\prime}$ & $\log \mathrm{K}_{1 \mathrm{y}}^{\circ}$ & $\log \beta_{1 y}^{\circ}$ & Method $^{\text {a) }}$ & Ref. \\
\hline $\begin{array}{l}1.0 \mathrm{M} \mathrm{HClO}_{4} / \mathrm{LiClO}_{4} \text {, room temp., } \\
10^{-8}-1 \mathrm{M} \mathrm{H}^{+}, 10^{-8} \mathrm{M}^{238} \mathrm{Pu}(\mathrm{IV})\end{array}$ & & & & extr & $\begin{array}{l}{[72 \mathrm{MET} / \mathrm{GUI}]} \\
{[73 \mathrm{MET}]}\end{array}$ \\
\hline $\mathrm{Pu}(\mathrm{OH})^{3+}$ & -0.45 & 0.60 & $14.6 \pm 0.2$ & & \\
\hline $\mathrm{Pu}(\mathrm{OH})_{2}{ }^{2+}$ & -1.2 & 0.63 & $28.6 \pm 0.3$ & & \\
\hline $\mathrm{Pu}(\mathrm{OH})_{3}^{+}$ & -4.5 & -2.25 & $39.7 \pm 0.4$ & & \\
\hline $\mathrm{Pu}(\mathrm{OH})_{4}(\mathrm{aq})$ & -10.8 & -8.54 & $47.5 \pm 0.5$ & & \\
\hline $\begin{array}{l}\text { 1.0 } \mathrm{M} \mathrm{HClO}_{4} / \mathrm{LiClO}_{4} \text {, room temp. } \\
10^{-3}-1 \mathrm{M} \mathrm{H}^{+},{ }^{239} \mathrm{~Np}(\mathrm{IV}) \text { trace conc. }\end{array}$ & & & & extr & [77DUP/GUI] \\
\hline $\mathrm{Np}(\mathrm{OH})^{3+}$ & -0.5 & 0.55 & $14.55 \pm 0.2$ & & \\
\hline $\mathrm{Np}(\mathrm{OH})_{2}{ }^{2+}$ & -1.5 & 0.35 & $28.35 \pm 0.3$ & & \\
\hline
\end{tabular}

Other data for $\mathrm{Pu}(\mathrm{OH})^{3+}$

$\log K_{11}^{\prime} \quad \log K_{11}^{\circ} \quad \log \beta_{11}^{\circ}$

\begin{tabular}{|c|c|c|c|c|c|}
\hline $\begin{array}{l}0.5 \mathrm{M} \mathrm{HCl} / \mathrm{NaCl}, 25^{\circ} \mathrm{C} \\
0.01-0.5 \mathrm{M} \mathrm{H}^{+}, 7.2 \cdot 10^{-4} \mathrm{M} \mathrm{Pu}(\mathrm{IV})\end{array}$ & -1.65 & -0.63 & 13.37 & spec & [50KRA/NEL] \\
\hline $\begin{array}{l}0.5 \mathrm{M} \mathrm{HClO}_{4} / \mathrm{NaClO}_{4}, 25^{\circ} \mathrm{C} \\
0.01-0.5 \mathrm{M} \mathrm{H}^{+}, 7.2 \cdot 10^{-4} \mathrm{M} \mathrm{Pu}(\mathrm{IV})\end{array}$ & -1.60 & -0.64 & 13.36 & spec & [50KRA/NEL] \\
\hline $\begin{array}{l}2.0 \mathrm{M} \mathrm{HClO}_{4} / \mathrm{NaClO}_{4}, 25^{\circ} \mathrm{C} \\
0.01-2.0 \mathrm{M} \mathrm{H}^{+}, 10^{-3} \mathrm{M} \mathrm{Pu}(\mathrm{IV})\end{array}$ & -1.73 & -0.70 & 13.30 & spec & {$[60 \mathrm{RAB} / \mathrm{KLI}]$} \\
\hline $\begin{array}{l}0.19 \mathrm{M} \mathrm{HClO}_{4}, 23^{\circ} \mathrm{C} \\
1.8 \cdot 10^{-3} \mathrm{M} \mathrm{Pu}(\mathrm{IV})\end{array}$ & -1.96 & -1.19 & 12.81 & spec & [68CLE] \\
\hline $\begin{array}{l}0.06 \mathrm{M} \mathrm{HClO}_{4}, 23^{\circ} \mathrm{C} \\
1.6 \cdot 10^{-3} \mathrm{M} \mathrm{Pu}(\mathrm{IV})\end{array}$ & -1.48 & -0.94 & 13.06 & spec & [68CLE] \\
\hline $\begin{array}{l}1.0 \mathrm{M} \mathrm{HClO}_{4} / \mathrm{NaClO}_{4}, 25^{\circ} \mathrm{C} \\
0.1-0.2 \mathrm{M} \mathrm{H}^{+}, 10^{-3} \mathrm{M} \mathrm{Pu}(\mathrm{IV})\end{array}$ & -1.51 & -0.45 & 13.55 & redox & [51RAB/LEM] \\
\hline $\begin{array}{l}2.0 \mathrm{M} \mathrm{HClO}_{4} / \mathrm{LiClO}_{4}, 25^{\circ} \mathrm{C} \\
0.1-2.0 \mathrm{M} \mathrm{H}^{+}, 8 \cdot 10^{-3} \mathrm{M} \mathrm{Pu}(\mathrm{IV})\end{array}$ & -1.27 & -0.24 & 13.76 & redox & [57RAB] \\
\hline
\end{tabular}

Other data for $\mathrm{Np}(\mathrm{OH})^{3+}$

$\begin{array}{llllll}2.0 \mathrm{M} \mathrm{HClO}_{4} / \mathrm{NaClO}_{4}, 25^{\circ} \mathrm{C} & -2.30 & -1.25 & 12.75 & \text { spec } & \text { [59SUL/HIN] } \\ 0.01-0.1 \mathrm{M} \mathrm{H}^{+},(1.4-2.7) \cdot 10^{-3} \mathrm{M} \mathrm{Np}(\mathrm{IV}) & & & & \\ 1.0 \mathrm{M} \mathrm{HClO}_{4} / \mathrm{NaClO}_{4}, 25^{\circ} \mathrm{C} & -1.90 & -0.84 & 13.16 & \text { spec } & \text { [70PAU] } \\ 0.01-0.2 \mathrm{M} \mathrm{H}^{+}, 7.5 \cdot 10^{-3} \mathrm{M} \mathrm{Np}(\mathrm{IV}) & & & & & \\ 1.0 \mathrm{M} \mathrm{HClO}_{4} / \mathrm{NaClO}_{4}, 25^{\circ} \mathrm{C} & -2.25 & -1.19 & 12.81 & \text { spec } & \text { [78FED/PER] }\end{array}$

a) extr $=$ solvent extraction spec $=$ spectroscopy redox $=\mathrm{Pu}(\mathrm{III}) / \mathrm{Pu}(\mathrm{IV})$ redox potential 
Figure 2.1 shows the fractions of mononuclear Pu(IV) hydrolysis species as a function of the $\mathrm{H}^{+}$concentration in carbonate-free solutions. It is calculated for $\mathrm{Pu}(\mathrm{IV})$ trace concentrations with the hydrolysis constants from Metivier and Guillaumont [72MET/GUI, 73MET]. According to this scheme, even in $1 \mathrm{M} \mathrm{HClO}_{4}$ the $\mathrm{Pu}^{4+}$ aquo ion is partially hydrolysed. In neutral to alkaline solutions, the tetrahydroxo complex $\mathrm{Pu}(\mathrm{OH})_{4}{ }^{\circ}$ (aq) is the predominant solution species. For Th(IV), U(IV) and Np(IV), a number of hydrolysis constants are not known. In order to obtain a complete set of formation constants for the mononuclear An(IV) hydrolysis species $\left(\log \beta^{\circ}{ }_{1 n}\right.$ with $\left.n=1-4\right)$, the unknown constants are estimated in the following section.

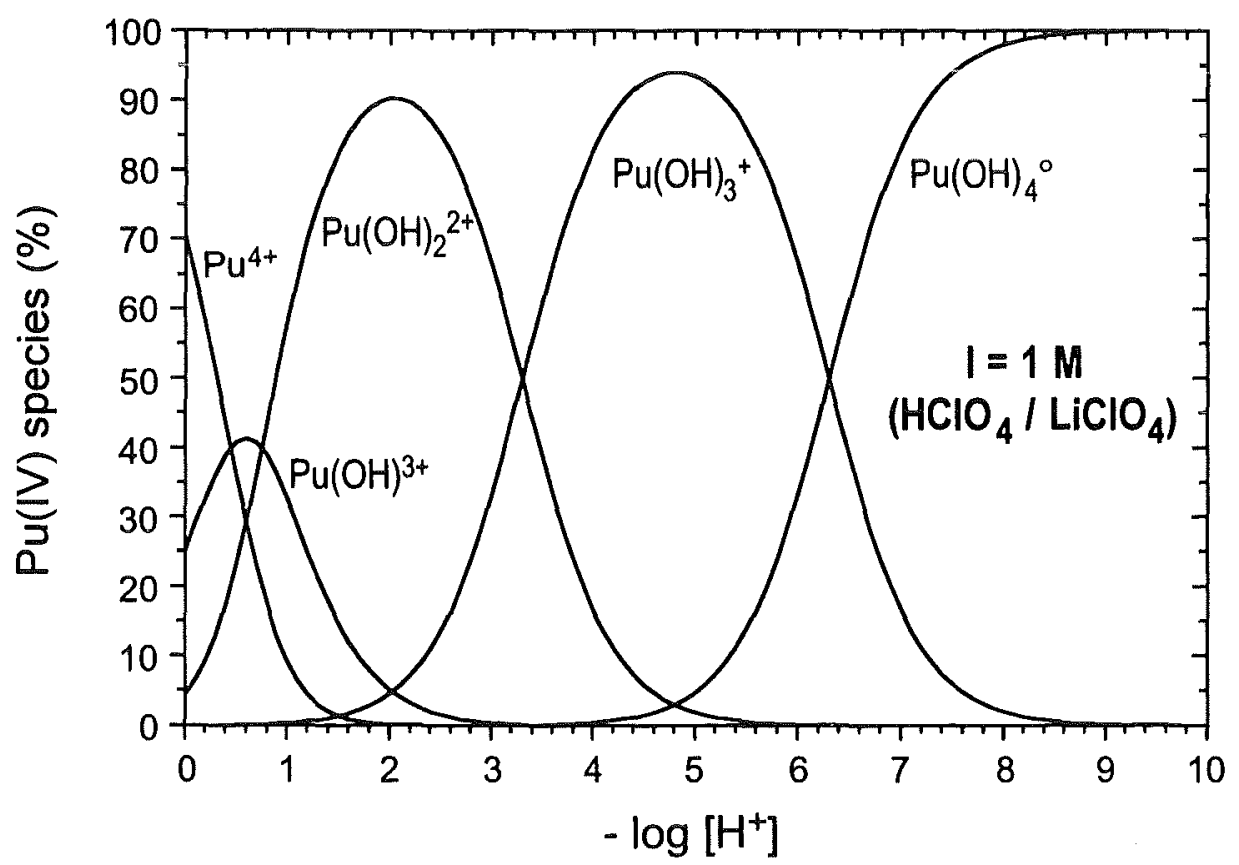

Fig. 2.1. $\mathrm{Pu}(\mathrm{IV})$ speciation scheme in carbonate-free $1 \mathrm{M} \mathrm{HClO}_{4} / \mathrm{LiClO}_{4}$ at $25^{\circ} \mathrm{C}$, calculated for $\mathrm{Pu}(\mathrm{IV})$ trace concentration with the hydrolysis constants given in [72MET/GUI, 73MET]. 


\subsection{Estimation of unknown constants}

If there are no specific peculiarities, complexation constants of metal ions with comparable electronic configuration depend on the electrostatic interaction energy between the metal and ligand ion [83CHO, 97GRE/PUI]:

$$
\begin{aligned}
& \log \beta^{\circ} \sim{ }^{e l} \mathrm{E}_{\mathrm{M}-\mathrm{L}} \sim\left(\mathrm{z}_{\mathrm{M}} / \mathrm{d}_{\mathrm{M}-\mathrm{L}}\right) \\
& \mathrm{Z}_{\mathrm{M}}=\text { charge of the metal ion } \\
& \mathrm{d}_{\mathrm{M}-\mathrm{L}}=\text { distance between the centers of metal and ligand ions }
\end{aligned}
$$

This empirical linear correlation is usually applied on the first complexation constant and used by Choppin [83CHO, 94CHO/RIZ] to estimate effective charges of $\mathrm{z}_{\mathrm{M}}=2.3 \pm 0.1$ and $3.2 \pm$ 0.1 for the penta- and hexavalent actinide ions $\mathrm{AnO}_{2}{ }^{+}$and $\mathrm{AnO}_{2}{ }^{2+}$, respectively. The distances $\mathrm{d}_{\mathrm{An}-\mathrm{OH}}$, given by the sum of the effective radii of the actinide ion $\mathrm{OH}^{-}$ions (the latter is assumed to be equal to that of a $\mathrm{H}_{2} \mathrm{O}$ molecule) are shown in Table 2.3.

Table 2.3. Distances $\mathrm{d}_{\mathrm{M}-\mathrm{OH}_{2}}$ and effective radii of lanthanide and actinide ions

\begin{tabular}{lccc}
\hline $\mathrm{M}$ & $\begin{array}{c}\mathrm{d}_{\mathrm{M}-\mathrm{OH}}(\AA){ }^{\mathrm{a})} \\
(\mathrm{XRD}, \text { EXAFS })\end{array}$ & \multicolumn{2}{c}{ Ionic radius $\mathrm{r}_{\mathrm{M}}(\AA)$} \\
& & & $1.14(\mathrm{CN}=8)$ \\
$\mathrm{Np}_{\mathrm{M}}=\mathrm{d}_{\mathrm{M}-\mathrm{OH}_{2}-\mathrm{r}_{\mathrm{H}_{2} \mathrm{O}}{ }^{3+}}$ & Crystal radius & \\
$\mathrm{Pu}^{3+}$ & $2.50 \pm 0.01$ & $1.12 \pm 0.02$ & $1.12(\mathrm{CN}=8)$ \\
$\mathrm{Am}^{3+}$ & & & $1.10(\mathrm{CN}=8)$ \\
$\mathrm{Cm}^{3+}$ & & & $1.09(\mathrm{CN}=8)$ \\
$\mathrm{Th}^{4+}$ & $2.46 \pm 0.02$ & $1.08 \pm 0.02$ & $1.09(\mathrm{CN}=9)$ \\
$\mathrm{U}^{4+}$ & $2.42 \pm 0.02$ & $1.04 \pm 0.02$ & $1.05(\mathrm{CN}=9)$ \\
$\mathrm{Np}^{4+}$ & $2.40 \pm 0.01$ & $1.02 \pm 0.02$ & $1.03(\mathrm{CN}=9)$ \\
$\mathrm{Pu}^{4+}$ & $2.39 \pm 0.01$ & $1.01 \pm 0.02$ & $1.01(\mathrm{CN}=9)$ \\
$\mathrm{NpO}_{2}{ }^{+}$ & $2.51 \pm 0.01$ & $1.13 \pm 0.02$ & \\
$\mathrm{UO}_{2}{ }^{2+}$ & $2.415 \pm 0.01$ & $1.035 \pm 0.02$ & \\
$\mathrm{PuO}_{2}{ }^{2+}$ & $2.40 \pm 0.01$ & $1.02 \pm 0.02$ & \\
\hline
\end{tabular}

a) from the compilation in [99NEC/KIM]

b) effective ionic radius in aqueous solution, calculated with $\mathrm{r}_{\mathrm{H}_{2} \mathrm{O}}=1.38 \pm 0.02 \AA$ [85MAR]

c) crystal radii [76SHA, 94CHO/RIZ] at given coordination number $(\mathrm{CN})$ 
Fig.2.2 shows the application of correlation (2.1) on the known hydrolysis constants for the actinides Am(III) and Cm(III) [98NEC/FAN], Np(IV) [77DUP/GUI], Pu(IV) [72MET/GUI], $\mathrm{NpO}_{2}{ }^{+}$[95FAN/NEC] and $\mathrm{UO}_{2}{ }^{2+}$ [91CHO/MAT]. The unknown formation constants of mononuclear hydrolysis species of Th(IV), U(IV) and $\mathrm{Np}(\mathrm{IV})$ estimated by interpolation are summarized in Table 2.4.

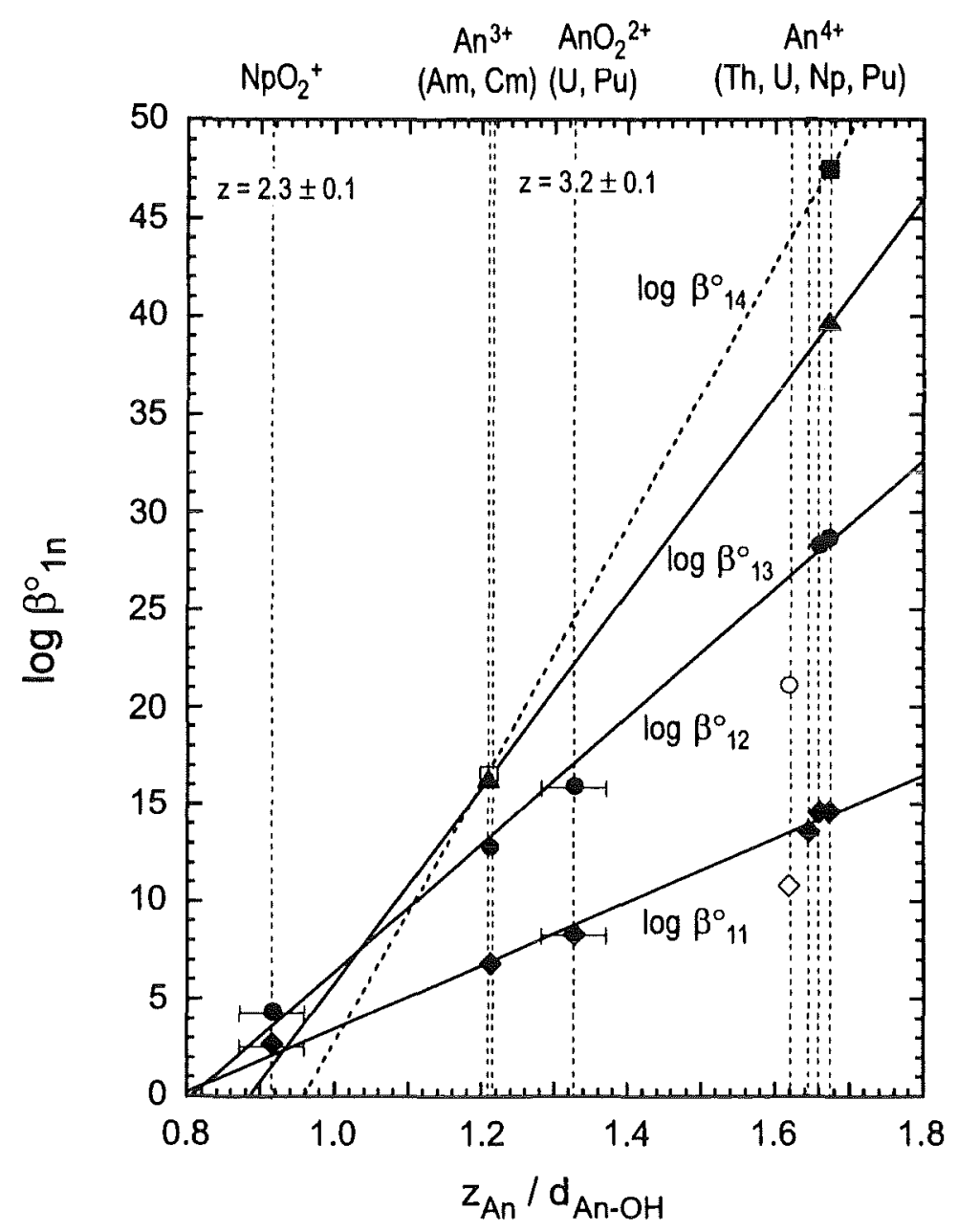

Fig. 2.2. Correlation between the hydrolysis constants and the electrostatic interaction energy between the actinide and $\mathrm{OH}^{-}$ions: $\log \beta^{\circ}{ }_{1 \mathrm{n}} \sim{ }^{\mathrm{el}} \mathrm{E}_{\mathrm{An}-\mathrm{OH}} \sim\left(\mathrm{z}_{\mathrm{An}} / \mathrm{d}_{\mathrm{An}-\mathrm{OH}}\right)$

Since the quotient $\mathrm{z}_{\mathrm{M}} / \mathrm{d}_{\mathrm{M}-\mathrm{OH}}$ increases slightly in the series $\mathrm{Th}(\mathrm{IV})<\mathrm{U}(\mathrm{IV})<\mathrm{Np}(\mathrm{IV})<\mathrm{Pu}(\mathrm{IV})$ a corresponding increase is expected for the $\log \beta^{\circ}$ values. However, the $\mathrm{Th}(\mathrm{IV})$ hydrolysis constants evaluated from potentiometric titration studies, e.g. those selected by Baes and Mesmer [76BAE/MES] for $\mathrm{Th}(\mathrm{OH})^{3+}$ and $\mathrm{Th}(\mathrm{OH})_{2}{ }^{2+}$, are several orders of magitude lower than expected (Fig.2.2). The large differences between the values reported for Th(IV) and those of other tetravalent actinides cannot be explained by the differences in the physical properties of the $\mathrm{An}^{4+}$ ions. This supports the doubts pointed out in section 2.1, concerning the interpretation of data from experimental studies, which are at least partly performed in 
oversaturated solutions. On the other hand, the estimated $\log \beta^{\circ}{ }_{1 \mathrm{n}}$ values in Table 2.4 are by no means experimentally confirmed.

Another estimation method is based on an electrostatic approach [99NEC/KIM], which correlates the mononuclear complexation constants $\log \beta^{\circ}$ in for a given actinide ion with an inter-ligand electrostatic repulsion energy term:

$$
\log {\beta^{\circ}}_{1 \mathrm{n}}=\mathrm{n} \log \beta^{\circ}{ }_{11}-{ }^{\text {rep }} \mathrm{E}_{\mathrm{L}} / \mathrm{RT} \ln 10
$$

The ligand repulsion term ${ }^{\text {rep }} \mathrm{E}_{\mathrm{L}}$ is calculated from the known charge and inter-distance of the ligands involved in a given complex and their angular distribution [99NEC/KIM]. The semiempirical coefficients required to describe the electrostatic shielding between the $\mathrm{OH}^{-}$ligands were derived from the known hydrolysis constants of Am(III) and Cm(III) [98NEC/FAN] and $\mathrm{Pu}(\mathrm{IV})$ [73MET/GUI]. The formation constants $\log \beta^{\circ}{ }_{13}$ and $\log \beta^{\circ}{ }_{14}$ for $\mathrm{Np}(\mathrm{IV})$, calculated from the known values $\log \beta^{\circ}{ }_{11}$ and $\log \beta^{\circ}{ }_{12}$, are in reasonable agreement with the estimates from correlation (2.1) (c.f. Table 2.4).

In general, it is hardly possible to give an uncertainty for the estimates derived by inter- or extrapolation with the described empirical and semi-empirical methods. In the following sections, these estimates are used assuming an uncertainty of \pm 1 logarithmic unit.

Table 2.4. Estimated formation constants for mononuclear An(IV) hydrolysis species

\begin{tabular}{|c|c|c|c|c|c|}
\hline & & Th(IV) & U(IV) & $\mathrm{Np}(\mathrm{IV})$ & $\mathrm{Pu}(\mathrm{IV})$ \\
\hline $\log {\beta^{\circ}}_{11}$ & $\begin{array}{l}\text { experim. } \\
\text { estimated }\end{array}$ & $\begin{array}{l}10.8 \pm 0.2 \\
13.4(\mathrm{~A})\end{array}$ & $\begin{array}{l}13.6 \pm 0.2 \\
13.8(\mathrm{~A})\end{array}$ & $\begin{array}{l}14.55 \pm 0.2 \\
14.2(\mathrm{~A}), 14.6(\mathrm{~B})\end{array}$ & $\begin{array}{l}14.6 \pm 0.2 \\
14.7(\mathrm{~B})\end{array}$ \\
\hline $\log \beta_{12}^{\circ}$ & $\begin{array}{l}\text { experim. }^{\text {a) }} \\
\text { estimated }^{\text {b) }}\end{array}$ & $\begin{array}{l}21.1 \pm 0.2 \\
26.5(\mathrm{~A})\end{array}$ & $27.5(\mathrm{~A})$ & $\begin{array}{l}28.3 \pm 0.3 \\
28.0(\mathrm{~A}), 28.2(\mathrm{~B})\end{array}$ & $\begin{array}{l}28.6 \pm 0.3 \\
28.4(\mathrm{~B})\end{array}$ \\
\hline $\log \beta^{\circ}{ }_{13}$ & $\begin{array}{l}\text { experim. } \\
\text { estimated }^{\text {b) }}\end{array}$ & $36.7(\mathrm{~A})$ & $38.2(\mathrm{~A})$ & $39.0(\mathrm{~A}), 39.2(\mathrm{~B})$ & $\begin{array}{l}39.7 \pm 0.3 \\
39.4(\mathrm{~B})\end{array}$ \\
\hline $\log \beta_{14}^{\circ}$ & $\begin{array}{l}\text { experim. }^{\text {a) }} \\
\text { estimated }^{\text {b) }}\end{array}$ & $43.9(\mathrm{~A})$ & $45.7(\mathrm{~A})$ & $46.6(\mathrm{~A}), 47.2(\mathrm{~B})$ & $\begin{array}{l}47.5 \pm 0.4 \\
47.5(\mathrm{~B})\end{array}$ \\
\hline
\end{tabular}

a) experim. data for Th(IV) from [76BAE/MES], U(IV) from [92FUG/KHO, 92GRE/FUG], $\mathrm{Np}(\mathrm{IV})$ from [77DUP/GUI] and Pu(IV) from [72MET/GUI]

b) (A): estimated from the correlation $\log \beta^{\circ} \sim\left(\mathrm{z}_{\mathrm{An}} / \mathrm{d}_{\mathrm{An}-\mathrm{OH}}\right)$

(B): estimated in [99NEC/KIM] from the equation $\log \beta^{\circ}{ }_{1 n}=n \log \beta^{\circ}{ }_{11}-{ }^{\text {rep }} E_{L} / R T \ln 10$ 


\section{An(IV) hydroxides and oxides}

The chemical form of freshly precipitated or aged An(IV) solid phases is not yet clear. In the literature, they are partly called amorphous hydroxides $\mathrm{An}(\mathrm{OH})_{4}(\mathrm{am})$, partly amorphous or microcrystalline hydrous oxides $\mathrm{AnO}_{2} \cdot \mathrm{xH}_{2} \mathrm{O}(\mathrm{s})$. The preparation of water-free crystalline dioxide $\mathrm{AnO}_{2}$ (cr) requires heating above $700^{\circ} \mathrm{C}$ [84GRE/LIE, 89KIM/KAN, 89MOO].

\subsection{Solubility products of crystalline $\mathrm{AnO}_{2}(\mathrm{cr})$}

Solubility data determined with crystalline $\mathrm{AnO}_{2}(\mathrm{cr})$ as initial solid phase imply a certain ambiguity. Because of the usually slow equilibration kinetics, hydration or amorphisation cannot be ruled out. It is not ascertained, whether the initial $\mathrm{AnO}_{2}(\mathrm{cr})$ remains the solubility limiting equilibrium solid phase, or whether the measured solubility data must be ascribed to a hydrated, less crystalline or even amorphous surface layer on the bulk crystalline solid.

It is more convenient to calculate the solubility products for $\mathrm{AnO}_{2}(\mathrm{cr})$ from thermochemical data. Knowing the molar standard enthalpies $\Delta_{\mathrm{f}} \mathrm{H}^{\circ}\left(\mathrm{AnO}_{2}(\mathrm{cr})\right)$, reasonable estimates for the molar standard entropies $\mathrm{S}^{\circ}\left(\mathrm{AnO}_{2}(\mathrm{cr})\right)$, and the thermodynamic standard data for the corresponding auxiliary compounds, the molar standard Gibbs energy of formation, $\Delta_{\mathrm{r}} \mathrm{G}^{\circ}\left(\mathrm{AnO}_{2}(\mathrm{cr})\right)$, is given by:

$$
\Delta_{\mathrm{f}} \mathrm{G}^{\circ}\left(\mathrm{AnO}_{2}(\mathrm{cr})\right)=\Delta_{\mathrm{f}} \mathrm{H}^{\circ}\left(\mathrm{AnO}_{2}(\mathrm{cr})\right)-\mathrm{T} \Delta_{\mathrm{f}} \mathrm{S}^{\circ}\left(\mathrm{AnO}_{2}(\mathrm{cr})\right)
$$

The value of $\log \mathrm{K}_{\mathrm{sp}}^{\circ}\left(\mathrm{AnO}_{2}(\mathrm{cr})\right)$ can then be calculated from the Gibbs energy for the dissolution reaction $\left(\Delta_{\mathrm{r}} \mathrm{G}^{\circ}\right)$ applying the general relations:

and

$$
\text { - RT } \ln \mathrm{K}^{\circ}=\Delta_{\mathrm{r}} \mathrm{G}^{\circ}=\Sigma \Delta_{\mathrm{f}} \mathrm{G}^{\circ} \text { (products) }-\sum \Delta_{\mathrm{f}} \mathrm{G}^{\circ} \text { (educts) }
$$

$$
\log \mathrm{K}^{\circ}=-\Delta_{\mathrm{r}} \mathrm{G}^{\circ} / \mathrm{RT} \ln 10
$$

with RT $\ln 10=5.708 \mathrm{~kJ} / \mathrm{mol}$ at $298.15 \mathrm{~K}\left(25^{\circ} \mathrm{C}\right)$ [92GRE/FUG]. Table 3.1 shows the solubility products for $\mathrm{ThO}_{2}(\mathrm{cr}), \mathrm{UO}_{2}(\mathrm{cr}), \mathrm{NpO}_{2}$ (cr) and $\mathrm{PuO}_{2}(\mathrm{cr})$ calculated by Rai et al. [87RAI/SWA]. They are based on critically evaluated standard data at $25^{\circ} \mathrm{C}: \Delta_{\mathrm{f}} \mathrm{H}^{\circ}\left(\mathrm{AnO}_{2}(\mathrm{cr})\right)$ and $\mathrm{S}^{\circ}\left(\mathrm{AnO}_{2}(\mathrm{cr})\right)$ from [72FUG], $\mathrm{S}^{\circ}(\mathrm{An}(\mathrm{cr}))$ from [76OET/RAN], $\Delta_{\mathrm{f}} \mathrm{G}^{\circ}\left(\mathrm{An}^{4+}(\mathrm{aq})\right)$ from [76FUG/OET], and $\Delta_{\mathrm{f}} \mathrm{G}^{\circ}\left(\mathrm{OH}^{-}(\mathrm{aq})\right), \Delta_{\mathrm{f}} \mathrm{G}^{\circ}\left(\mathrm{H}_{2} \mathrm{O}(\mathrm{l})\right)$ and $\mathrm{S}^{\circ}\left(\mathrm{O}_{2}(\mathrm{~g})\right)$ from [82WAG/EVA]. Slightly different values for $\Delta_{\mathrm{f}} \mathrm{G}^{\circ}$ and $\log \mathrm{K}^{\circ}$ sp were calculated in [89KIM/KAN] for $\mathrm{PuO}_{2}(\mathrm{cr})$ and in the NEA review on uranium [92GRE/FUG] for $\mathrm{UO}_{2}(\mathrm{cr})$. 
Table 3.1. Solubility products for crystalline $\mathrm{An}(\mathrm{IV})$ dioxides, $\log \mathrm{K}_{\mathrm{sp}}^{\circ}\left(\mathrm{AnO}_{2}(\mathrm{cr})\right)$, calculated from thermochemical standard data at $25^{\circ} \mathrm{C}$

\begin{tabular}{llll}
\hline Th(IV) & U(IV) & Np(IV) & Pu(IV) \\
\hline$-54.2 \pm 1.3^{\text {a) }}$ & $-60.6 \pm 0.5^{\text {a) }}$ & $-63.7 \pm 1.8^{\text {a) }}$ & $-64.1 \pm 0.7^{\text {a) }}$ \\
& $-60.86 \pm 0.36^{\text {b) }}$ & & $\left.-63.8 \pm 1.0^{c}\right)$ \\
\hline
\end{tabular}

a) $[87 \mathrm{RAI} / \mathrm{SWA}]$, b) $[92 \mathrm{GRE} / \mathrm{FUG}]$, c) $[89 \mathrm{KIM} / \mathrm{KAN}]$

\subsection{Solubility products of amorphous hydroxides / hydrous oxides}

In the following sections, the An(IV) hydrolysis constants evaluated in chapter 2, both experimental data and estimated values are used together to evaluate the thermodynamic solubility products from the experimental solubility data hitherto available in the literature.

If there are no complexes with other inorganic ligands or colloidal species present in solution, the total An(IV) concentration in equilibrium with $\mathrm{AnO}_{2} \cdot \mathrm{xH}_{2} \mathrm{O}(\mathrm{s})$ or $\mathrm{An}(\mathrm{OH})_{4}(\mathrm{am})$ is given by

$$
\begin{aligned}
{[\mathrm{An}]_{\mathrm{tot}} } & =\left[\mathrm{An}^{4+}\right]+\Sigma \mathrm{x}\left[\mathrm{An}_{\mathrm{x}}(\mathrm{OH})_{\mathrm{y}}{ }^{4 \mathrm{x}-\mathrm{y}}\right] \\
& \left.=\mathrm{K}_{\mathrm{sp}}^{\prime}\left[\mathrm{OH}^{-}\right]^{-\mathrm{n}}+\Sigma \mathrm{x}\left(\mathrm{K}_{\mathrm{sp}}^{\prime}\left[\mathrm{OH}^{-}\right]^{-\mathrm{n}}\right)^{\mathrm{x}} \beta_{\mathrm{xy}}\left[\mathrm{OH}^{-}\right]^{\mathrm{y}}\right)
\end{aligned}
$$

In neutral and alkaline solutions, which are of greatest interest for natural goundwater systems, salt or cement brines, $\mathrm{An}(\mathrm{OH})_{4}(\mathrm{aq})$ is the predominant aqueous species. The dissolution equilibrium can hence be written as

$$
\mathrm{AnO}_{2} \cdot \mathrm{xH}_{2} \mathrm{O}(\mathrm{s})+(2-\mathrm{x}) \mathrm{H}_{2} \mathrm{O} \Leftrightarrow \mathrm{An}(\mathrm{OH})_{4}(\mathrm{aq})
$$

The $\mathrm{pH}$-independent solubility in this range is given by:

$$
\log [\mathrm{An}(\mathrm{IV})]_{\mathrm{tot}} \approx \log \left[\mathrm{An}(\mathrm{OH})_{4}(\mathrm{aq})\right]=\log \mathrm{K}_{\mathrm{sp}}^{\prime}+\log \beta_{14}^{\prime}
$$

In neutral and alkaline solution of low ionic strength ( $\mathrm{I} \leq 1 \mathrm{~mol} / \mathrm{l})$, the solubility is also independent of the medium and ionic strength: $\left(\log \mathrm{K}_{\text {sp }}+\log \beta^{\prime}{ }_{14}\right) \approx\left(\log \mathrm{K}^{\circ}{ }_{\mathrm{sp}}+\log \beta^{\circ}{ }_{14}\right)$, because the water activity and the activity coefficients of $\mathrm{An}(\mathrm{OH})_{4}(\mathrm{aq})$ are approximately equal to $1\left(\sum \mathrm{m}_{\mathrm{i}} \varepsilon\left(\mathrm{An}(\mathrm{OH})_{4}(\mathrm{aq}) / \mathrm{i}\right) \approx 0\right)$. 


\subsubsection{Plutonium(IV)}

The solubility of amorphous $\mathrm{Pu}(\mathrm{IV})$ precipitates, $\mathrm{Pu}(\mathrm{OH})_{4}(\mathrm{am})$ or $\mathrm{PuO}_{2} \cdot \mathrm{xH}_{2} \mathrm{O}(\mathrm{s})$, has been investigated over several decades. However, there are large discrepancies among the published solubility products (c.f. reviews in [98CAP/VIT, 89KIM/KAN]). Particularly at $\mathrm{pH}>1$, $\mathrm{Pu}(\mathrm{IV})$ is easily oxidised to $\mathrm{Pu}(\mathrm{V})$, which disproportionates into $\mathrm{Pu}(\mathrm{III})$ and $\mathrm{Pu}(\mathrm{VI})$ [92CAP/VIT, 98CAP/VIT, 84RAI]. Therefore, the oxidation state of the aqueous species has to be controlled by solvent extraction or spectroscopic methods, as done in [98CAP/VIT, $89 \mathrm{KIM} / \mathrm{KAN}, 84 \mathrm{RAI}, 49 \mathrm{KAS}$ ] and partly in [86LIE/KIM]. The presence of plutonium species of other oxidation states can lead to an overestimation of the $\mathrm{Pu}(\mathrm{IV})$ solubility, if the aqueous speciation is not controlled. The data of Pérez-Bustamente [65PER] in $0.001-0.03$ $\mathrm{M} \mathrm{HClO}_{4}$ (Fig.3.1.b), which suggest an almost $\mathrm{pH}$-independent solubility in the range $\mathrm{pH}=$ 1.5 - 3.5, represent a typical example for this effect. Similar data, with aqueous plutonium species of other oxidation states being predominant, were reported in [80RAI/SER, 82RAI/RYA, 86LIE/KIM, 90PAZ/KUD]. Since the fraction of dissolved Pu(IV) is not known for these solubility data, they are disregarded in the considerations below. Contributions from $\mathrm{Pu}(\mathrm{IV})$ colloids is another possible source of error. As demonstrated by $\mathrm{Kim}$ and Kanellakopulos [89KIM/KAN], colloidal $\mathrm{Pu}(\mathrm{IV})$ polymers can be present even at $\mathrm{pH}=0-1$ and total $\mathrm{Pu}$ concentration below $10^{-3} \mathrm{~mol} / \mathrm{l}$. However, the reported solubility data were usually measured after filtration in order to minimize this effect. According to the filtration and LIBD experiments in [96KNO], the greatest part of colloidal $\mathrm{Pu}(\mathrm{IV})$ is removed by filtration with filter pore sizes of 400 and $1 \mathrm{~nm}$.

The $\mathrm{Pu}(\mathrm{IV})$ solubilities reported in $1 \mathrm{M} \mathrm{HClO}_{4} / \mathrm{NaClO}_{4}$ and in acidic solutions of low ionic strength are shown in Figs. 3.1.a and 3.1.b, respectively. Neglecting polynuclear and colloidal species and applying the hydrolysis constants of Metivier and Guillaumont [72MET/GUI] (c.f. Table 2.2), the solubility product of amorphous $\mathrm{Pu}(\mathrm{IV})$ hydroxide or hydrous oxide is calculated from the different solubility data at $I=0.06-1 \mathrm{~mol} / \mathrm{l}$ (Table 3.2 ). The mean value is found to be

$$
\log \mathrm{K}_{\mathrm{sp}}^{\circ}=-58.7 \pm 0.9
$$

Fig.3.1.b indicates that the hydrolysis constants from [72MET/GUI] correctly predict the $\mathrm{pH}$-dependence of the solubility curve. Within the range of uncertainty, the calculated solubility covers all experimental data, even a couple of data reported in [86LIE/KIM] for ${ }^{239} \mathrm{PuO}_{2}(\mathrm{~s})$ in $0.1-5 \mathrm{M} \mathrm{NaCl}$ in the range $\mathrm{pH}=3-7$. 

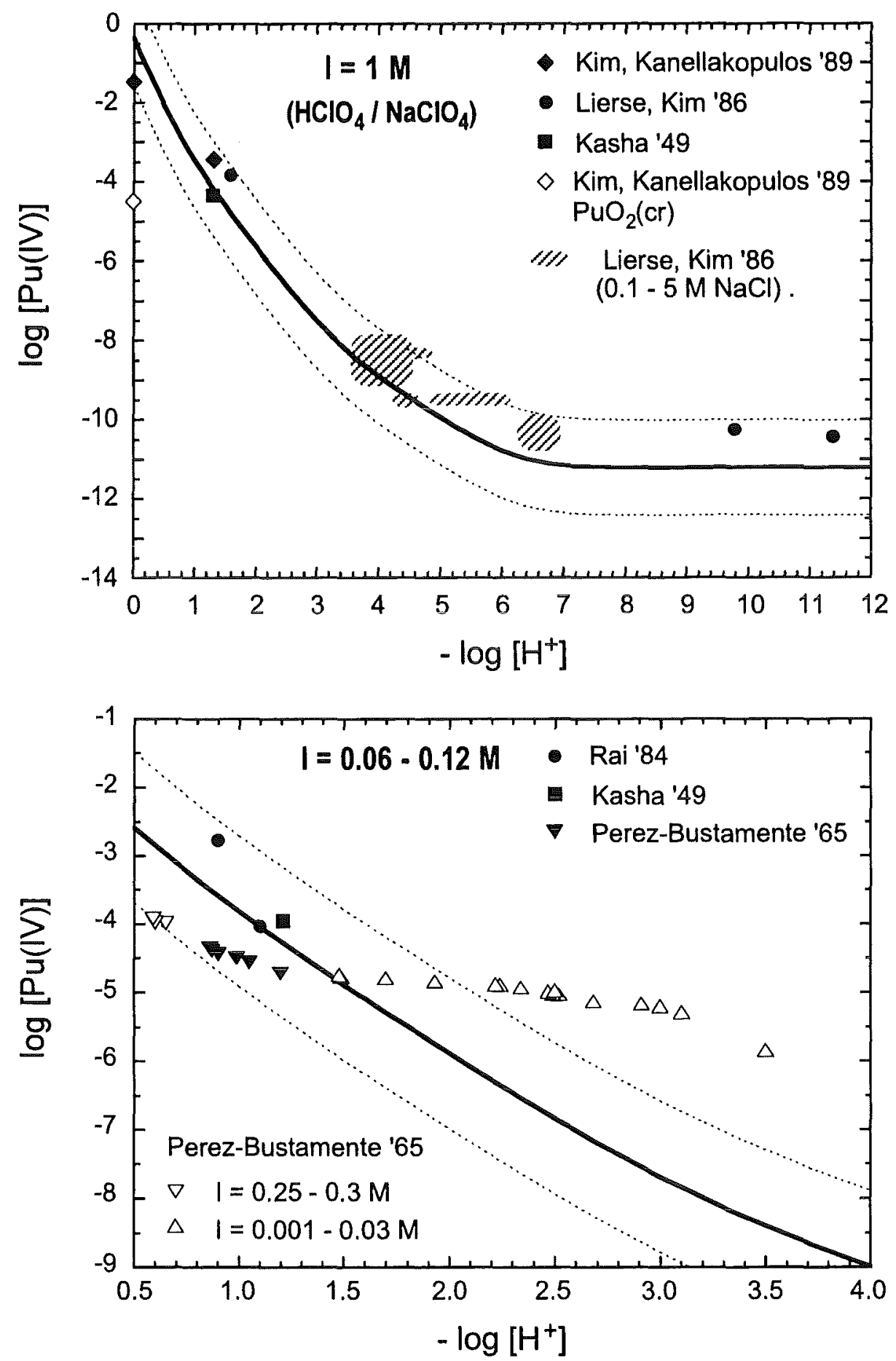

Fig. 3.1. Solubility of $\mathrm{Pu}(\mathrm{IV})$ hydrous oxide as a function of the $\mathrm{H}^{+}$concentration at $20-25^{\circ} \mathrm{C}$. a) in $1 \mathrm{M} \mathrm{HClO}_{4} / \mathrm{NaClO}_{4}$ (above), b) in acidic solutions at low ionic strength (below). The experimental data are from [49KAS, 65PER, 84RAI, 86LIE/KIM, $89 \mathrm{KIM} / \mathrm{KAN}]$. The solid lines are calculated for $\mathrm{I}=1$ and $0.1 \mathrm{M}$, respectively, with $\log \mathrm{K}_{\text {sp }}^{\circ}=-58.7$ and the hydrolysis constants from [72MET/GUI]. The dotted lines show the range of uncertainty. 
Table 3.2. Experimental solubility data for $\mathrm{Pu}(\mathrm{IV})$ hydroxide / hydrous oxide at $20-25^{\circ} \mathrm{C}$, and the solubility products $\log \mathrm{K}_{\mathrm{sp}}^{\prime}$ (molar scale) and $\log \mathrm{K}_{\mathrm{sp}}^{\circ}$ calculated with the hydrolysis constants and SIT coefficients selected in the present report

\begin{tabular}{|c|c|c|c|}
\hline Authors / Medium & $\log [\mathrm{Pu}(\mathrm{IV})]_{\mathrm{tot}}$ & $\log \mathrm{K}_{\mathrm{sp}}$ & $\log \mathrm{K}_{\mathrm{sp}}^{\circ}$ \\
\hline \multicolumn{4}{|l|}{ Kasha [49KAS] } \\
\hline $1 \mathrm{M} \mathrm{NaClO}_{4} / 0.05 \mathrm{M} \mathrm{H}^{+}$ & -4.34 & $-55.9 \pm 0.3$ & $-58.9 \pm 0.3$ \\
\hline $0.06 \mathrm{M} \mathrm{HCl}$ & -3.95 & $-56.6 \pm 0.3$ & $-58.4 \pm 0.3$ \\
\hline \multicolumn{4}{|l|}{ Pérez-Bustamente [65PER] } \\
\hline $0.06-0.12 \mathrm{M} \mathrm{HClO}_{4}$ & -4.72 to -4.35 & $-57.4 \pm 0.4$ & $-59.4 \pm 0.4$ \\
\hline $0.25-0.29 \mathrm{M} \mathrm{HClO}_{4}$ & $-3.96 \pm 0.03$ & $-57.3 \pm 0.3$ & $-59.9 \pm 0.3$ \\
\hline \multicolumn{4}{|l|}{ Rai [84RAI] } \\
\hline $\mathrm{I}=0.112 \mathrm{M}, \mathrm{pH}=1.00^{\mathrm{a})}$ & -2.77 & $-55.8 \pm 0.3$ & $-58.0 \pm 0.3$ \\
\hline $\mathrm{I}=0.064 \mathrm{M}, \mathrm{pH}=1.20^{\mathrm{a})}$ & -4.03 & $-56.9 \pm 0.3$ & $-58.7 \pm 0.3$ \\
\hline \multicolumn{4}{|l|}{ Lierse and $\mathrm{Kim}$ [86LIE/KIM] } \\
\hline $\left.1 \mathrm{M} \mathrm{NaClO}_{4}, \mathrm{pH}_{\exp }=1.38^{\mathrm{b}}\right)$ & -3.83 & $-54.8 \pm 0.3$ & $-57.8 \pm 0.3$ \\
\hline $1 \mathrm{M} \mathrm{NaClO}_{4}, \mathrm{pH}_{\text {exp }}=9-12$ & $-10.4 \pm 0.4$ & $-54.9 \pm 0.6$ & $-57.9 \pm 0.6$ \\
\hline \multicolumn{4}{|c|}{ Kim and Kanellakopulos [89KIM/KAN] } \\
\hline $1 \mathrm{M} \mathrm{HClO}_{4}$ & $\begin{array}{l}-1.48 \\
(-2.20\end{array}$ & $\begin{array}{l}-56.9 \pm 0.2 \\
-57.4 \pm 0.2\end{array}$ & $\begin{array}{l}-59.9 \pm 0.3 \\
-60.4 \pm 0.3)^{c)}\end{array}$ \\
\hline $1 \mathrm{M} \mathrm{NaClO}_{4}, \mathrm{pH}_{\exp }=1.09^{\mathrm{b})}$ & -3.44 & $-55.0 \pm 0.3$ & $-58.0 \pm 0.3$ \\
\hline \multicolumn{4}{|c|}{ Capdevila and Vitorge [98CAP/VIT] } \\
\hline$I=0$ & & & $-58.3 \pm 0.5$ \\
\hline $0.1 \mathrm{M} \mathrm{HClO}_{4}$ & & $-55.9 \pm 0.3^{d)}$ & $-58.0 \pm 0.3$ \\
\hline $0.1 \mathrm{M} \mathrm{HClO}_{4} / 0.4 \mathrm{M} \mathrm{NaClO}_{4}$ & & $-55.7 \pm 0.3^{d)}$ & $-58.7 \pm 0.3$ \\
\hline $0.1 \mathrm{M} \mathrm{HClO}_{4} / 0.9 \mathrm{M} \mathrm{NaClO}_{4}$ & & $-55.0 \pm 0.3^{d)}$ & $-58.0 \pm 0.3$ \\
\hline $0.1 \mathrm{M} \mathrm{HClO}_{4} / 1.9 \mathrm{M} \mathrm{NaClO}_{4}$ & & $-56.0 \pm 0.3^{d)}$ & $-58.4 \pm 0.3$ \\
\hline $0.1 \mathrm{M} \mathrm{HClO}_{4} / 2.9 \mathrm{M} \mathrm{NaClO}_{4}$ & & $-56.7 \pm 0.3^{d)}$ & $-58.1 \pm 0.3$ \\
\hline
\end{tabular}

a) The $\mathrm{H}^{+}$concentration is derived from $\mathrm{pH}=-\log \left[\mathrm{H}^{+}\right]-\log \gamma_{\mathrm{H}^{+}}$by calculating the activity coefficients $\gamma_{\mathrm{H}^{+}}$with the SIT equation.

b) The $\mathrm{H}^{+}$concentration is calculated with the relation: $\log \left[\mathrm{H}^{+}\right]=-\mathrm{pH}_{\exp }-0.23$ [96FAN/NEC] for $\mathrm{pH}$ measuremeants with Ross electrodes $\left(3 \mathrm{M} \mathrm{NaCl}\right.$ junction) in $1 \mathrm{M} \mathrm{NaClO}_{4}$

c) Calculated with the spectroscopically determined value of $\log \left[\mathrm{Pu}^{4+}\right]=-2.20$

d) Determined by an indirect method, independent of $\mathrm{Pu}(\mathrm{IV})$ hydrolysis reactions (see text) 
From the experimental solubility determined by Kim and Kanellakopulos [89KIM/KAN] with crystalline $\mathrm{PuO}_{2}$ (cr) equilibrated for 3 years in $1 \mathrm{M} \mathrm{HClO}_{4}(\log [\mathrm{Pu}(\mathrm{IV})]=-4.5 \pm 0.2$, c.f. Fig.3.1.a), a solubility product of $\log \mathrm{K}_{\text {sp }}^{\circ}=-62.9 \pm 0.4$ is calculated. This value is somewhat less negative than the thermodynamic solubility product calculated for $\mathrm{PuO}_{2}$ (cr) from thermochemical data $(-63.8 \pm 1.0$ [89KIM/KAN], $-64.1 \pm 0.7$ [87RAI/SWA]).

Capdevila and Vitorge [98CAP/VIT] evaluated the solubility product of amorphous $\mathrm{Pu}(\mathrm{IV})$ hydroxide by an indirect method, which is independent of $\mathrm{Pu}(\mathrm{IV})$ hydrolysis reactions. The solubility of $\mathrm{Pu}(\mathrm{OH})_{4}(\mathrm{am})$ was investigated under conditions, where $\mathrm{PuO}_{2}^{+}, \mathrm{PuO}_{2}{ }^{2+}$ and $\mathrm{Pu}^{3+}$ are the predominant aqueous species. Their concentrations were determined spectroscopically. When the disproportionation reaction $\mathrm{Pu}(\mathrm{V}) \Leftrightarrow \mathrm{Pu}(\mathrm{III})+\mathrm{Pu}(\mathrm{VI})$ reaches the equilibrium state, the $\mathrm{Pu}^{4+}$ concentration can be calculated from the known redox potentials $\mathrm{E}\left(\mathrm{Pu}^{4+} / \mathrm{Pu}^{3+}\right)$ and $\mathrm{E}\left(\mathrm{PuO}_{2}{ }^{2+} / \mathrm{PuO}_{2}{ }^{+}\right)$. The solubility product at $\mathrm{I}=0$ was obtained from their experimental data in $0.1-3 \mathrm{M} \mathrm{NaClO}_{4}$ using the SIT extrapolation method:

$$
\log \mathrm{K}_{\mathrm{sp}}^{\circ}=-58.3 \pm 0.5[98 \mathrm{CAP} / \mathrm{VIT}]
$$

The results of Capdevila and Vitorge [98CAP/VIT] are in good agreement with the $\log \mathrm{K}_{\text {sp }}^{\circ}$ value determined in the present study from experimental $\mathrm{Pu}(\mathrm{IV})$ solubility data and the hydrolysis constants given in [72MET/GUI]. This is noteworthy, because the calculations are based on completely different, independent methods. An unweighted average (with the uncertainty covering the whole range of expectance) can be recommended for the thermodynamic solubility product of amorphous $\mathrm{Pu}(\mathrm{IV})$ hydroxide or hydrous oxide:

$\log \mathrm{K}_{\mathrm{sp}}^{\circ}=-58.5 \pm 1.1$ 


\subsubsection{Neptunium(IV)}

The solubility of $\mathrm{Np}$ (IV) hydrous oxide in acidic solutions has been investigated by Rai et al. [87RAI/SWA] in the presence of $\mathrm{CuCl} / \mathrm{CuCl}_{2}$ redox buffer in solutions of low ionic strength $(\mathrm{I}=0.02-0.04 \mathrm{~mol} / \mathrm{l})$. The oxidation state of the dissolved neptunium, $\mathrm{Np}(\mathrm{IV})$ and $\mathrm{Np}(\mathrm{V})$, was determined by solvent extraction with TTA. Based on $\log \mathrm{K}_{11}^{\circ}=-1.5$ and neglecting further hydrolysis species, the solubility product was calculate to be $\log \mathrm{K}_{\text {sp }}^{\circ}=-54.5 \pm 0.3$. This value is generally accepted in the literature and numerous data bases. However, according to the hydrolysis constants selected in section 2.1 , the hydrolysis of $\mathrm{Np}(\mathrm{IV})$ is considerably underestimated in the calculation of Rai et al. [87RAI/SWA]. Accepting the hydrolysis constants from Duplessis and Metivier [77DUP/GUI] $\left(\log \beta^{\circ}{ }_{11}=14.5 \pm 0.2, \log \beta^{\circ}{ }_{12}=28.3\right.$ \pm 0.3 ) the following thermodynamic solubility product is calculated from the experimental data given in [87RAI/SWA]:

$$
\log \mathrm{K}_{\mathrm{sp}}^{\mathrm{o}}=-56.7 \pm 0.4
$$

A couple of their experimental data were disregarded in [87RAI/SWA], because the dissolved $\mathrm{Np}$ (IV) was only about $5 \%$ of the total $\mathrm{Np}$ concentration. Within the range of uncertainty, these data agree well with the present calculation (solid line in Fig.3.2.). In order to calculate the solubility of $\mathrm{NpO}_{2} \cdot \mathrm{xH}_{2} \mathrm{O}(\mathrm{am})$ over the whole $\mathrm{pH}$ range, estimated formation constants for the species $\mathrm{Np}(\mathrm{OH})_{3}{ }^{+}$and $\mathrm{Np}(\mathrm{OH})_{4}(\mathrm{aq})\left(\log \beta^{\circ}{ }_{13}=39.2\right.$ and $\log \beta^{\circ}{ }_{14}=47.2$ [99NEC/KIM]) were used in combination with the values of $\log \mathrm{K}_{\mathrm{sp}}^{\mathrm{o}}, \log \beta^{\circ}{ }_{11}$ and $\log \beta^{\circ}{ }_{12}$ given above. The solubility predicted for solutions at $\mathrm{pH}>6\left(\log \left[\mathrm{Np}(\mathrm{OH})_{4}(\mathrm{aq})\right]=-9.5 \pm 1\right)$ is somewhat lower than the available experimental data. Rai et al. [85RAI/RYA] determined the solubility in $\mathrm{NaOH}$ solutions containing reducing agents $\left(\mathrm{Na}_{2} \mathrm{~S}_{2} \mathrm{O}_{4}, \mathrm{Fe}\right.$ or $\left.\mathrm{Zn}\right)$ and Eriksen et al. [93ERI/NDA] in $0.5 \mathrm{M} \mathrm{NaClO}_{4}$ containing $\mathrm{Na}_{2} \mathrm{~S}_{2} \mathrm{O}_{4}$. The observed neptunium concentrations were at or below the detection limit (log $[\mathrm{Np}] \leq-8.3 \pm 0.3)$. Similar results (log $[\mathrm{Np}]$ in the range -8 to -9.5 ) were reported by Nakayama et al. [96NAK/YAM] at $\mathrm{pH}=6-14$ in 0.1 and $1 \mathrm{M} \mathrm{NaClO}_{4} / \mathrm{NaOH}$ solutions containing $\mathrm{Na}_{2} \mathrm{~S}_{2} \mathrm{O}_{4}, \mathrm{Fe}$ or $\mathrm{Cu}$. Since the oxidation state of $\mathrm{Np}$ can hardly be ascertained as $\mathrm{Np}(\mathrm{IV})$, when the concentration is at the detection limit, small contributions of oxidised $\mathrm{Np}(\mathrm{V})$ can increase the total $\mathrm{Np}$ concentration. In order to cover these uncertainties the following values are selected:

and

$$
\log \left[\mathrm{Np}(\mathrm{OH})_{4}(\mathrm{aq})\right]=\log \mathrm{K}_{\mathrm{sp}}^{\circ}+\log \beta_{14}^{\circ}=-9.0 \pm 1.0
$$

$$
\log \beta_{14}^{\circ}=47.7 \pm 1.1
$$

There is no indication for the formation of $\mathrm{Np}(\mathrm{OH})_{5}{ }^{-}$at $\mathrm{pH}=12-14$ [85RAI/RYA, 93ERI/NDA, 96NAK/YAM]. 


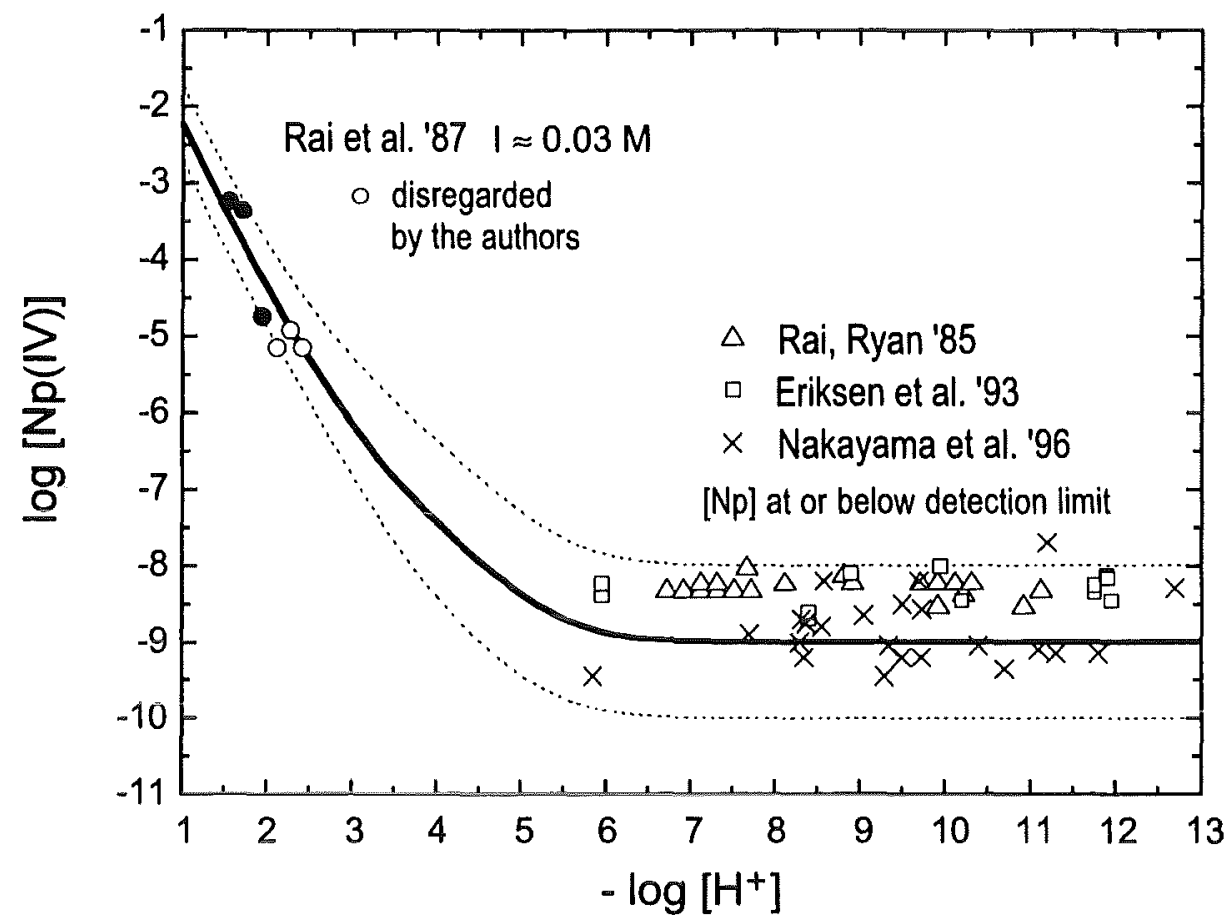

Fig. 3.2. Solubility of $\mathrm{Np}(\mathrm{IV})$ hydrous oxide as a function of the $\mathrm{H}^{+}$concentration at $25^{\circ} \mathrm{C}$;

Experimental data in acidic solutions of low ionic strength from [87RAI/SWA], in the range $\mathrm{pH}=6-13$ from [85RAI/RYA, 93ERI/NDA, 96NAK/YAM].

The solid lines are calculated for $\mathrm{I}=0.03 \mathrm{M}$, with $\log \mathrm{K}_{\text {sp }}^{\circ}=-56.7, \log \beta^{\circ}{ }_{11}, \log \beta^{\circ}{ }_{12}$ from [77DUP/GUI], $\log \beta^{\circ}{ }_{13}$ estimated in [99NEC/KIM] and $\log \beta^{\circ}{ }_{14}=47.7$.

The dotted lines show the range of uncertainty. 


\subsubsection{Uranium(IV)}

The solubilities reported in the literature for hydrous $\mathrm{UO}_{2} \cdot \mathrm{xH}_{2} \mathrm{O}(\mathrm{s})$, amorphous or microcrystalline $\mathrm{UO}_{2}$ (s) differ extremely. As pointed out in the NEA review [92GRE/FUG], they probably do not refer to a unique material, but rather to a range of solids with different thermodynamic stabilities.

In order to evaluate thermodynamic data for an amorphous solid phase of $\mathrm{UO}_{2}$, the present calculations are based on solubility data obtained with fresh or amorphous precipitates at 20 $25^{\circ} \mathrm{C}$. Rai et al. [90RAI/FEL, 97RAI/FEL] determined the solubility of $\mathrm{UO}_{2} \cdot \mathrm{xH}_{2} \mathrm{O}(\mathrm{am})$, which was found to be X-ray amorphous before and after the solubility experiments, in $\mathrm{NaCl}$ and $\mathrm{MgCl}_{2}$ solutions of various ionic strength. Fe powder and $\mathrm{EuCl}_{2}$ were added to prevent U(IV) from oxidation. An earlier study was performed in alkaline $\mathrm{NaOH} / \mathrm{Na}_{2} \mathrm{~S}_{2} \mathrm{O}_{4}$ solutions containing $\mathrm{Zn}$ powder [83RYA/RAI]. In comparable studies of Yajima et al. [95YAJ/KAW] (in $0.1 \mathrm{M} \mathrm{NaClO}_{4}$ ) and Grambow et al. [99GRA/MÜL] (in $1 \mathrm{M} \mathrm{NaCl}$ ), redox conditions were controlled electrochemically. The experimental data in solutions of $\mathrm{I}=0.03-0.2 \mathrm{~mol} / \mathrm{l}$ and in 1.0 $\mathrm{M} \mathrm{NaCl}$ are shown in Figs. 3.3.a and b, respectively.

Rai et al. [90RAI/FEL, 97RAI/FEL] emphasized that it is very difficult to maintain properly reducing conditions. Even traces of dissolved oxygen cause at least partly oxidation of U(IV) to $\mathrm{U}(\mathrm{VI})$. It was clearly demonstrated that the great solubilities reported by Bruno et at al. [87BRU/CAS] and Gayer and Leider [57GAY/LEI] $(\log [\mathrm{U}]=-4.4 \pm 0.4$ at $\mathrm{pH} 5-10$ in 0.5 $\mathrm{M} \mathrm{NaClO}_{4}$ and -5.3 to -4.2 in alkaline $\mathrm{NaOH}$ solutions, respectively) were caused by oxidised $\mathrm{U}(\mathrm{VI})$ species [90RAI/FEL]. The concentration of $\mathrm{U}(\mathrm{OH})_{4}(\mathrm{aq})$ in equilibrium with $\mathrm{UO}_{2} \cdot \mathrm{xH}_{2} \mathrm{O}(\mathrm{am})$ was estimated to be about $10^{-8.0} \mathrm{~mol} / 1$, and a couple of data with greater concentrations in the neutral and alkaline range were ascribed to the presence of U(VI) [90RAI/FEL]. As discussed in [83RYA/RAI, 90RAl/FEL] there is no experimental prove for the formation of $\mathrm{U}(\mathrm{OH})_{5}{ }^{-}$at high $\mathrm{pH}$ as claimed in earlier reviews, e.g. in [76BAE/MES].

In order to calculate the solubility product of $\mathrm{UO}_{2} \cdot \mathrm{xH}_{2} \mathrm{O}(\mathrm{am})$, the solubility at $\mathrm{pH}<5$ is described by applying $\log \beta^{\circ}{ }_{11}=13.6$ and the estimated values for $\log \beta^{\circ}{ }_{12}$ and $\log \beta^{\circ}{ }_{13}$ from Table 2.4 (section 2.2). Based on the solubility data from [90RAI/FEL, 97RAI/FEL] in chloride solutions of $\mathrm{I} \leq 1 \mathrm{~mol} / \mathrm{l}$, and the data obtained in [99GRA/MÜL] from oversaturation, i.e. with a fresh precipitate of $\mathrm{UO}_{2} \cdot \mathrm{xH}_{2} \mathrm{O}(\mathrm{am})$, the following solubility product is calculated:

$$
\log \mathrm{K}_{\mathrm{sp}}^{\circ}=-55.2 \pm 1.0
$$



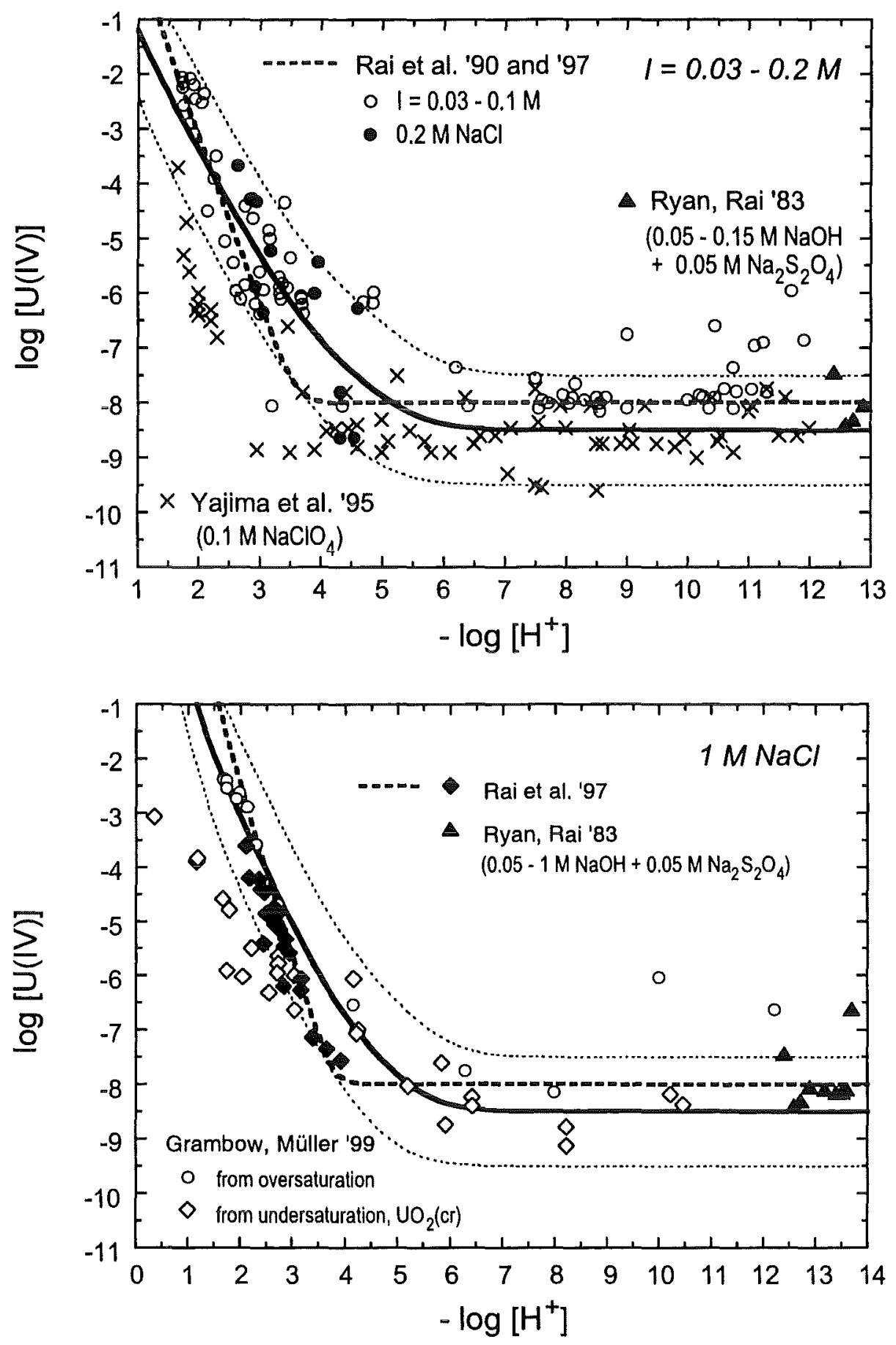

Fig. 3.3. Solubility of $\mathrm{UO}_{2}(\mathrm{~s})$ as a function of the $\mathrm{H}^{+}$concentration at $20-25^{\circ} \mathrm{C}$, a) at $\mathrm{I}=0.03-0.2 \mathrm{~mol} / 1$ (above), b) in $1 \mathrm{M} \mathrm{NaCl}$ (below). The experimental data are from [90RAI/FEL, 97RAI/FEL, 83RYA/RAI, 95YAJ/KAW, 99GRA/MÜL]. The solid lines are calculated for $\mathrm{I}=0.1$ and $1 \mathrm{M} \mathrm{NaCl}$, respectively, with $\log \mathrm{K}_{\text {sp }}^{\circ}=$ $-55.2 \pm 1$ and the hydrolysis constants selected in the present report (Table 3.3). The dashed line is calculated with the model proposed by Rai et al. [90RAI/FEL, 97RAI/FEL]. The dotted lines show the range of uncertainty 
The calculated solubility is shown as solid lines in Fig. 3.3. The dashed lines represent the solubilities predicted by the model of Rai et al. [90RAI/FEL, 97RAI/FEL], which includes only the hydrolysis species $\mathrm{U}(\mathrm{OH})^{3+}$ and $\mathrm{U}(\mathrm{OH})_{4}(\mathrm{aq})$. Yajima et al. [95YAJ/KAW] proposed an even simpler scheme, neglecting all hydrolysis species except of $\mathrm{U}(\mathrm{OH})_{4}(\mathrm{aq})$. Since the latter authors observed an increase in crystallinity with the time of alteration, their lower solubilties in the range $\mathrm{pH}<5$ must be ascribed to a more crystalline, thermodynamically more stable solid phase compared to the precipitates in [90RAI/FEL, 97RAI/FEL, 99GRA/MÜL]. The different sets of thermodynamic data are summarized in Table 3.3.

In contrast to the data at low $\mathrm{pH}$, the solubilities at $\mathrm{pH}>5$ show no significant dependence on the initial solid phase, either fresh precipitates in oversaturation experiments or electrodeposited and crystalline $\mathrm{UO}_{2}(\mathrm{~s})$ in undersaturation experiments [99GRA/MÜL]. In $[95 \mathrm{YAJ} / \mathrm{KAW}]$ a value of $\log \left[\mathrm{U}(\mathrm{OH})_{4}(\mathrm{aq})\right]=-8.7 \pm 0.4$ was derived from both, over- and undersaturation experiments, independent of the degree of crystallinity. Considering as well the value proposed in $[90 \mathrm{RAI} / \mathrm{FEL}]\left(\log \left[\mathrm{U}(\mathrm{OH})_{4}(\mathrm{aq})\right] \approx-8.0\right)$, the following constants are selected:

and

$$
\log \left[\mathrm{U}(\mathrm{OH})_{4}(\mathrm{aq})\right]=\log \mathrm{K}_{\mathrm{sp}}^{\circ}+\log {\beta^{\circ}}_{14}=-8.5 \pm 1.0
$$

$$
\log \beta^{\circ}{ }_{14}=46.7 \pm 1.4
$$

They are one order of magnitude larger, i.e. within the range of error in fair agreement with the values estimated in section $2.2\left(\log \beta^{\circ}{ }_{14}=45.7 \pm 1.0\right.$ and hence $\log \left[\mathrm{U}(\mathrm{OH})_{4}(\mathrm{aq})\right]=-9.5 \pm 1.4$

Table 3.3. Thermodynamic constants proposed in the literature for modelling the solubility of amorphous $\mathrm{UO}_{2} \times \mathrm{xH}_{2} \mathrm{O}(\mathrm{s})$ at $25^{\circ} \mathrm{C}$ as a function of $\mathrm{pH}$

\begin{tabular}{lccc}
\hline & $\begin{array}{l}\text { Rai et al. } \\
{[90 \mathrm{RAI} / \mathrm{FEL}]} \\
{[97 \mathrm{RAI} / \mathrm{FEL}]}\end{array}$ & $\begin{array}{c}\text { Yajima et al. } \\
{[95 \mathrm{YAJ} / \mathrm{KAW}]}\end{array}$ & present study \\
\hline $\log \mathrm{K}_{\text {sp }}^{\circ}$ & -53.45 & $-55.7 \pm 0.3$ & $-55.2 \pm 1.0$ \\
$\log \beta^{\circ}{ }_{11}$ & 13.5 & - & $13.6 \pm 0.2$ \\
$\log \beta_{12}^{\circ}$ & - & - & $(27.5 \pm 1.0)^{\mathrm{a})}$ \\
$\log \beta_{13}^{\circ}$ & - & - & $(38.2 \pm 1.0)^{\mathrm{a})}$ \\
$\log \beta^{\circ}$ & 45.45 & $47.0 \pm 0.5$ & $46.7 \pm 1.0^{\mathrm{b})}$ \\
\hline
\end{tabular}

a) estimated values (c.f. section 2.2)

b) calculated from $\left[\mathrm{U}(\mathrm{OH})_{4}(\mathrm{aq})\right]=\log \mathrm{K}^{\circ}{ }_{\mathrm{sp}}\left(\mathrm{UO}_{2} \cdot \mathrm{xH}_{2} \mathrm{O}(\mathrm{am})\right)+\log \beta^{\circ}{ }_{14}=-8.5 \pm 1$ 
for amorphous $\mathrm{UO}_{2} \cdot \mathrm{xH}_{2} \mathrm{O}(\mathrm{am})$ ). This means that the experimental solubility data at $\mathrm{pH}>5$ refer to an amorphous precipitate, independent of the initial solid phase used. Moon [89MOO] reported similar observations for Th(IV): At low $\mathrm{pH}$, the solubility of $\mathrm{ThO}_{2}$ (cr) was found to be essentially lower than that of $\mathrm{Th}(\mathrm{OH})_{4}(\mathrm{am})$, but at $\mathrm{pH}>5$ equal thorium concentrations of $\log \left[\mathrm{Th}(\mathrm{OH})_{4}(\mathrm{aq})\right]=-8.2 \pm 0.3$ were observed (c.f. section 3.2.4). Consequently, in the $\mathrm{pH}$ range, where $\mathrm{An}(\mathrm{OH})_{4}(\mathrm{aq})$ is the predominant aqueous species, the bulk crystalline solid must be covered with an amorphous, solubility limiting surface layer.

\section{Remarks on the present reevaluation of the thermodynamic solubiliy product}

The solubility calculated with the present set of constants is in fair agreement with the model calculations of Rai et al. [97RAI/FEL] (c.f. Fig.3.3). Therefore, these solubility data alone do certainly not justify the significantly different thermodynamic constants reevaluated in the present study. However, the objective of the present calculations is the evaluation of a more realistic set of constants, which is also consistent with other thermodynamic data for U(IV), e.g. data on carbonate complexation.

In a recent study, Rai et al [98RAI/FEL] determined the solubility of $\mathrm{UO}_{2} \cdot \mathrm{xH}_{2} \mathrm{O}(\mathrm{am})$ in the system $\mathrm{K}-\mathrm{Na}-\mathrm{HCO}_{3}-\mathrm{CO}_{3}-\mathrm{OH}-\mathrm{H}_{2} \mathrm{O}$ up to concentrated carbonate solutions. The pentacarbonate complex $\mathrm{U}\left(\mathrm{CO}_{3}\right)_{5}{ }^{6-}$ could be clearly identified as limiting complex by accompanying EXAFS investigations, and the corresponding solubiliy data were modeled with the Pitzer approach. Fitting simultaneously ion interaction parameters for the complex $\mathrm{U}\left(\mathrm{CO}_{3}\right)_{5}{ }^{6-}$, the thermodynamic equilibrium constant for the reaction

$$
\mathrm{UO}_{2}(\mathrm{am})+5 \mathrm{CO}_{3}{ }^{2-}+4 \mathrm{H}^{+}<=\mathrm{U}\left(\mathrm{CO}_{3}\right)_{5}^{6-}+2 \mathrm{H}_{2} \mathrm{O}
$$

was found to be $\log \mathrm{K}^{\circ}=33.8$, which corresponds to $\left(\log \mathrm{K}^{\circ}\right.$ sp $\left.+\log \beta^{\circ}\right)=-22.2$. Applying the value of $\log \mathrm{K}_{\mathrm{sp}}^{\mathrm{o}}=-53.45$ [97RAI/FEL], the formation constant of $\mathrm{U}\left(\mathrm{CO}_{3}\right)_{5}{ }^{6-}$ is calculated to be $\log \beta^{\circ}{ }_{5}=31.3$ [98RAI/FEL]. This value is about three orders of magnitude lower than $\log \beta^{\circ}{ }_{5}=34.0 \pm 0.9$ evaluated by Grenthe et al. [92GRE/FUG] from spectroscopic studies, $\log \beta^{\circ}{ }_{3}$ for $\mathrm{UO}_{2}\left(\mathrm{CO}_{3}\right)_{3}{ }^{4-}$ and the redox potential $\mathrm{U}(\mathrm{IV}) / \mathrm{U}(\mathrm{VI})$ in acidic and $\mathrm{Na}_{2} \mathrm{CO}_{3} / \mathrm{NaClO}_{4}$ solutions. Of course, the Pitzer model applied by Rai et al. [98RAI/FEL] and the SIT approach applied in the NEA-TDB for ionic strength corrections can lead to differing constants at $I=0$, particularly for highly charged species. However, these discrepancies should not exceed $0.5-1.0 \log$ units. On the other hand, using $\left(\log \mathrm{K}^{\circ}{ }_{\mathrm{sp}}+\log \beta^{\circ}{ }_{5}\right)=-22.2$ from [98RAI/FEL] and $\log \mathrm{K}^{\circ}$ sp $=-55.2 \pm 1.0$ as reevaluated in the present study, the calculated formation constant $\log \beta^{\circ}{ }_{5}=33.0 \pm 1.0$ agrees fairly well (within the range of uncertainty) with the value given in the NEA review on uranium [92GRE/FUG]. 


\section{Solubility of $\mathrm{UO}_{2}(s)$ at elevated temperature}

Parks and Pohl [85PAR/POH] investigated the solubility of crystalline uraninite in diluted chloride solutions ( $\mathrm{I} \leq 0.1 \mathrm{~mol} / \mathrm{l}, \mathrm{pH}=1.0-10.4)$ at $100-300^{\circ} \mathrm{C}$ under a pressure of $500 \mathrm{bar}$ $\mathrm{H}_{2}$. No significant dependence on temperature could be observed (Fig.3.4). The constant solubilities measured at $\mathrm{pH}>4\left(\log \left[\mathrm{U}(\mathrm{OH})_{4}(\mathrm{aq})\right]=-9.5 \pm 0.6\right)$ are close to the data at $25^{\circ} \mathrm{C}$. The solubilities in acidic solutions were found to be very low. At $\mathrm{pH}=1-2$ they are comparable with the solubility calculated for $\mathrm{UO}_{2}(\mathrm{cr})$ at $25^{\circ} \mathrm{C}$ with $\log \mathrm{K}_{\mathrm{sp}}^{\circ}\left(\mathrm{UO}_{2}(\mathrm{cr})\right)=-60.85$, derived from $\Delta_{\mathrm{f}} \mathrm{G}^{\circ}\left(\mathrm{UO}_{2}(\mathrm{cr})\right)=-1031.83 \pm 1.00 \mathrm{~kJ} / \mathrm{mol}$ [92GRE/FUG]. The comparison between the experimental solubility data at $100-300^{\circ} \mathrm{C}$ and the calculated solubility curves at $25^{\circ} \mathrm{C}$ (Fig.3.4) provides further evidence for the assumption that the solubility data at $\mathrm{pH}>5$ do not refer to $\mathrm{UO}_{2}(\mathrm{cr})$, but rather to an amorphous phase.

The high temperature data on the $\mathrm{pH}$-independent solubility of $\mathrm{UO}_{2}(\mathrm{cr})$ at $\mathrm{pH}>4$ were used in the NEA review on uranium [92GRE/FUG] to calculate thermodynamic standard data $\left(\Delta_{\mathrm{f}} \mathrm{G}^{\circ}, \mathrm{S}^{\circ}, \mathrm{C}_{\mathrm{p}}{ }^{\circ}\right)$ for the species $\mathrm{U}(\mathrm{OH})_{4}(\mathrm{aq})$ at $25^{\circ}$. It must be emphasized that these calculations are based on the assumption that $\mathrm{UO}_{2}(\mathrm{cr})$ remains the equilibrium solid phase, which is not consistent with the present interpretation.

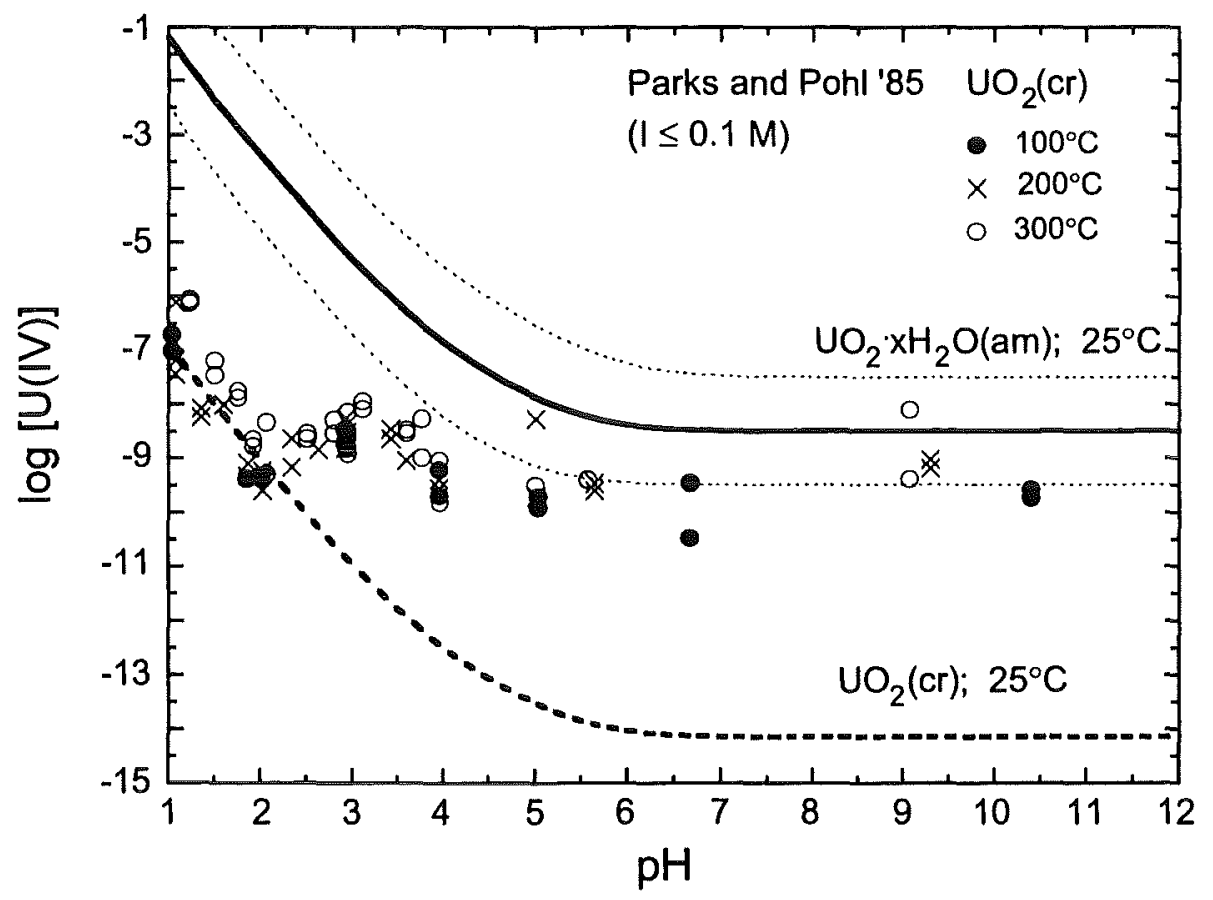

Fig. 3.4. Solubility of $\mathrm{UO}_{2}$ (cr) at 100,200 and $300^{\circ} \mathrm{C}$ (from [85PAR/POH]) and the calculated solubility of $\mathrm{UO}_{2} \cdot \mathrm{xH}_{2} \mathrm{O}(\mathrm{am})$ and $\mathrm{UO}_{2}(\mathrm{cr})$ in $0.1 \mathrm{M} \mathrm{NaCl}$ at $25^{\circ} \mathrm{C}$.

The calculations at $25^{\circ} \mathrm{C}$ are based on the constants evaluated in the present work and $\log \mathrm{K}_{\mathrm{sp}}^{\circ}\left(\mathrm{UO}_{2}(\mathrm{cr})\right)=-60.85 \pm 0.3[92 \mathrm{GRE} / \mathrm{FUG}]$. 


\subsubsection{Thorium(IV)}

Because of the limited knowledge on the mononuclear hydrolysis and the strong tendency to form polynuclear and colloidal species, the solubility of $\mathrm{Th}$ (IV) and its thermodynamic interpretation is discussed very controversially in the literature. The effect of polynucleation reactions has been neglected in the thermodynamic interpretation of $\mathrm{Pu}(\mathrm{IV}), \mathrm{Np}(\mathrm{IV})$ and U(IV) solubility data. However, in the case of Th(IV) it is of essential importance, because at low $\mathrm{pH}, \mathrm{Th}(\mathrm{IV})$ hydrous oxide or hydroxide is considerably more soluble.

Th(IV) solubilities determined at $25^{\circ} \mathrm{C}$ or room temperature are shown in Figs. 3.5.a (in $0.1 \mathrm{M}$ $\left.\mathrm{NaClO}_{4}\right)$ and 3.5.b (0.5 M NaClO $4,0.6 \mathrm{M} \mathrm{NaCl}$ and $\left.\mathrm{KCl}\right)$. Rai et al. [87RYA/RAI, 91FEL/RAI] described their equilibibrium solid phase in $0.1 \mathrm{M} \mathrm{NaClO}_{4}$ and in $0.6 \mathrm{M} \mathrm{NaCl}$ and $\mathrm{KCl}$ as $\mathrm{Th}(\mathrm{IV})$ hydous oxide, Moon [89MOO] and Nabivanets and Kudritskaya [64NAB/KUD] and Moon [89MOO] as Th(IV) hydroxide. Moon [89MOO] also determined the solubility in $0.1 \mathrm{M} \mathrm{NaClO}_{4}$ with crystalline $\mathrm{ThO}_{2}(\mathrm{cr})$ prepared at $750^{\circ} \mathrm{C}$. The solubilities measured at low $\mathrm{pH}$ are orders of magnitude below those of the amorphous precipitates. Similar observations were reported by Östhols et al. [94ÖST/BRU] for microcrystalline $\mathrm{ThO}_{2} \cdot \mathrm{xH}_{2} \mathrm{O}(\mathrm{s})$ prepared by drying an amorphous precipitate at room temperature in a vaccuum desiccator. At $\mathrm{pH}>6$ the solubility curves obtained with amorphous precipitates and $\mathrm{ThO}_{2}$ (cr) as initial solid phase match each other. In this range, $\mathrm{Th}(\mathrm{OH})_{4}(\mathrm{aq})$ is the predominant equilibrium aqueous species and probably the surface of $\mathrm{ThO}_{2}$ (cr) is covered with $\mathrm{Th}(\mathrm{OH})_{4}(\mathrm{~s})$ as solubility limiting solid phase. The $\mathrm{pH}$-independent solubilities measured in the range $\mathrm{pH}=6-13\left(\log [\mathrm{Th}]=-8.2 \pm 0.3\right.$ in 0.1 and $0.5 \mathrm{M} \mathrm{NaClO}_{4}$ [89MOO], $-8.8 \pm 0.2$ in $0.1 \mathrm{M} \mathrm{NaClO}_{4}$ [87RYA/RAI] and $-8.5 \pm 0.6$ in $0.6 \mathrm{M} \mathrm{NaCl}$ and $\mathrm{KCl}$ [91FEL/RAI]), are in fair agreement. The significantly higher solubilities reported by Nabivanets and Kudritskaya [64NAB/KUD] $\left(\log [\mathrm{Th}]=-6.3\right.$ at $\mathrm{pH}=5.5-7$ in $\left.0.1 \mathrm{M} \mathrm{NaClO}_{4}, 17^{\circ} \mathrm{C}\right)$ are disregarded. These authors applied only centrifugation for phase separation, whereas in the other studies, the thorium concentration was determined after ultrafiltration (filter pore size about $2 \mathrm{~nm}$ [87RYA/RAI, 91FEL/RAI, 89MOO] or 10 - $220 \mathrm{~nm}$ [94ÖST/BRU]).

The solubility data at $\mathrm{I}=0.5-0.6 \mathrm{~mol} / \mathrm{l}$ obtained by Felmy, Rai and Mason [91FEL/RAI] and Moon [89MOO] with an amorphous precipitate of Th(IV) hydrous oxide or hydroxide agree within the range of scattering of their experimental data (Fig.3.5.b). Despite this fact, extremely different solubility products were evaluated (c.f. Table.3.4), because Rai et al. [97RAI/FEL, 91FEL/RAI] neglected all hydrolysis species except $\mathrm{Th}(\mathrm{OH})_{4}(\mathrm{aq})$, whereas Moon [89MOO] simultaneously fitted formation constants for mono- and dinuclear hydrolysis species. 

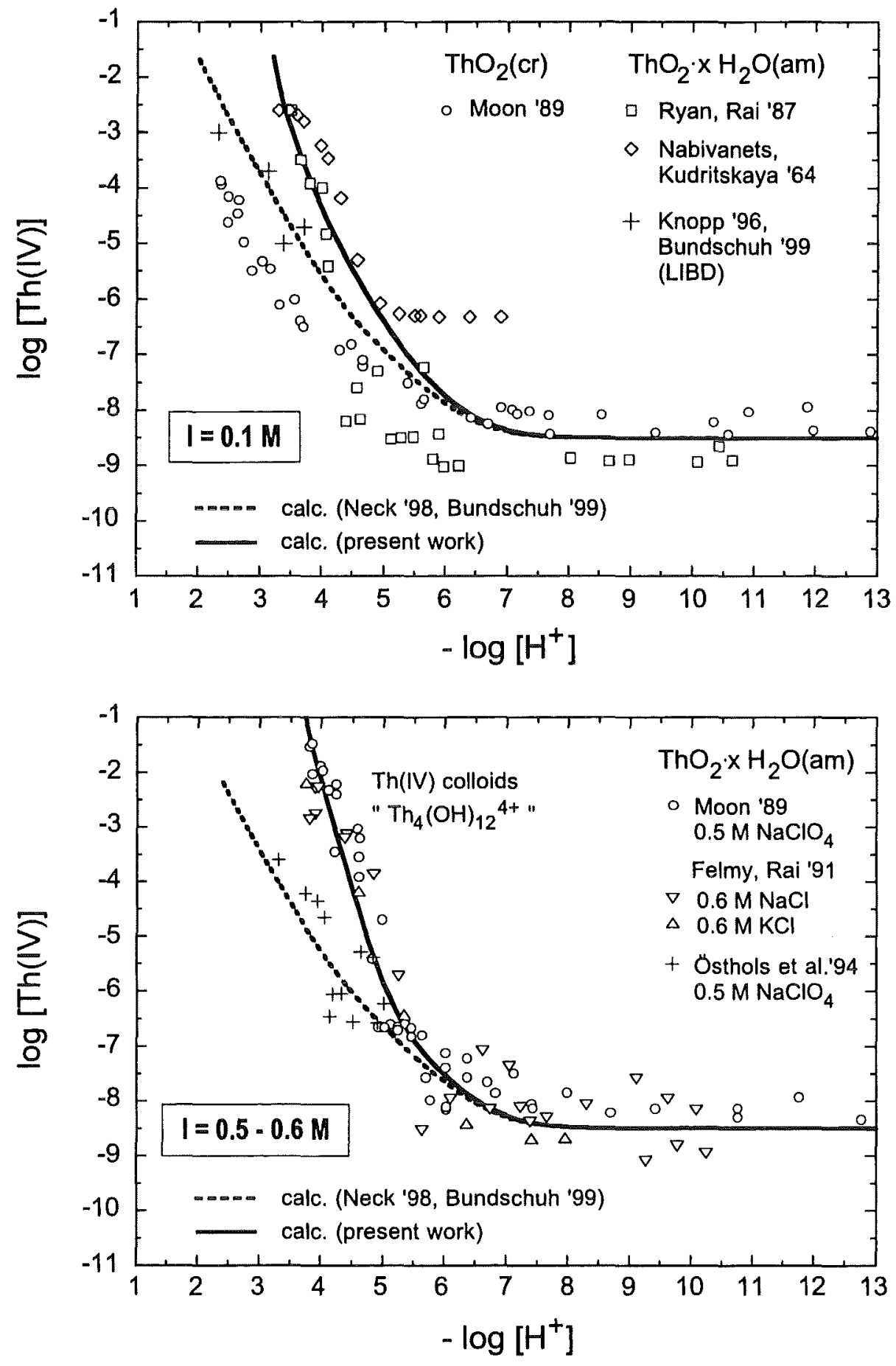

Fig. 3.5. Solubility of $\mathrm{Th}(\mathrm{IV})$ at $20-25^{\circ} \mathrm{C}$ as a function of the $\mathrm{H}^{+}$concentration a) in $0.1 \mathrm{M}$ $\mathrm{NaClO}_{4}$ (above) and b) at I $=0.5-0.6 \mathrm{~mol} / \mathrm{l}$ (below). The solubility curves calculated for amorphous $\mathrm{Th}(\mathrm{IV})$ hydroxide or hydrous oxide are based on different chemical models and thermodynamic constants:

- - - calculated with mononuclear hydrolysis constants $\log \beta^{\circ}{ }_{1 y}$ estimated in [98NEC, 99BUN] and $\log \mathrm{K}_{\mathrm{sp}}^{\circ}=-52.4$

— based on $\log \beta^{\circ}$ vy values for mono- and polynuclear species from [83BRO/ELL] and $\log \mathrm{K}_{\mathrm{sp}}^{\circ}=-47.2$ 
Table 3.4. Thermodynamic constants proposed in the literature for modelling the solubility of amorphous $\mathrm{ThO}_{2} \mathrm{xH}_{2} \mathrm{O}(\mathrm{s})$ at $25^{\circ} \mathrm{C}$ as a function of $\mathrm{pH}$

\begin{tabular}{lllll}
\hline & $\begin{array}{l}\text { Rai et al. } \\
{[97 R A I / F E L]} \\
{[91 F E L / R A I]}\end{array}$ & $\begin{array}{l}\text { Moon } \\
{[89 M O O]}\end{array}$ & $\begin{array}{l}\text { Östhols et al. } \\
\text { [94ÖST/BRU] }\end{array}$ & $\begin{array}{l}\text { Neck [98NEC] } \\
\text { Bundschuh [99BUN] }\end{array}$ \\
\hline $\log \mathrm{K}_{\text {sp }}^{\circ}$ & -45.5 & -52.9 & -48.7 & -52.4 \\
$\log \beta_{11}^{\circ}$ & - & 13.3 & 10.9 & 13.4 \\
$\log \beta_{12}^{\circ}$ & - & 23.9 & - & 26.5 \\
$\log \beta_{13}^{\circ}$ & - & 36.3 & 32.9 & 36.7 \\
$\log \beta_{14}^{\circ}$ & 37.0 & 44.7 & $(42.1)^{\mathrm{b})}$ & 43.9 \\
$\log \beta_{23}^{\prime}$ & & $32.2^{\text {a) }}$ & & \\
$\log \beta_{24}^{\prime}$ & & $59.1^{\text {a) }}$ & & \\
\hline
\end{tabular}

a) in $0.5 \mathrm{M} \mathrm{NaClO}_{4}$

b) This constant leads to $\left[\mathrm{Th}(\mathrm{OH})_{4}(\mathrm{aq})\right]=\log \mathrm{K}^{\circ}{ }_{\mathrm{sp}}+\log {\beta^{\circ}}_{14}=-6.6 \pm 0.2$, which is comparable with the solubilities given in [64NAB/KUD], although Östhols et al. themselves report that in carbonate-free solutions of high $\mathrm{pH}$, the thorium solubilities were below their detection limit of $10^{-7.5} \mathrm{~mol} / \mathrm{l}$.

Knopp [96KNO] studied the generation and stability of Th(IV) colloids by means of Laser induced breakdown detection (LIBD). The $\mathrm{pH}$ of $1 \cdot 10^{-3}, 2 \cdot 10^{-4}$, and $2 \cdot 10^{-5} \mathrm{M} \mathrm{Th}(\mathrm{IV}$ ) solutions in $0.1 \mathrm{M} \mathrm{HClO}_{4}$ was increased stepwise by adding $\mathrm{NaOH}$ until the formation of colloids (diameter $>10 \mathrm{~nm}$ ) was detected. In a similar experiment, $\mathrm{pH}$ was increased by dilution with water [99BUN]. Considering colloids as small solid phase particles formed as a prestep of precipitation, their formation indicates that the total thorium concentration exceeds the thermodynamic solubility of an amorphous hydroxide or hydrous oxide. The solubility data evaluated by this method are shown in Fig.3.5.a. The greater solubilities reported by other authors must hence be attributed to the presence of colloids. Based on the mononuclear hydrolysis constants estimated from the correlation in Fig.2.2, the solubility was calculated to be $-52.4 \pm 0.9$ [98NEC, 99BUN]. The $\mathrm{pH}$-dependent solubility predicted with this set of constants (Table 3.4) is shown as dashed lines in Figs. 3.5.a. and b. The thus calculated solubility curve agrees also fairly well with the experimental data obtained by Östhols et al. [94ÖST/BRU] in $0.5 \mathrm{M} \mathrm{NaClO}_{4}$ with microcrystalline $\mathrm{ThO}_{2} \mathrm{xH}_{2} \mathrm{O}(\mathrm{s})$ (Fig.3.5.b), although these authors proposed significantly different thermodynamic constants (c.f. Table 3.4).

With respect to the ambiguities concerning the solubility, colloid formation and hydrolysis of Th(IV), the present knowledge does not allow to decide, which of the proposed sets of constants in Table 3.4 is the most realistic one. Therefore, an attempt is made to evaluate a set 
of thermodynamic constants, which is at least fairly consistent with both, potentiometric titration studies and solubilities of amorphous precipitates. For this purpose, the hydrolysis constants derived in [83BRO/ELL] (Table 2.1) by potentiometric titrations in $0.1 \mathrm{KNO}_{3}$ and $\mathrm{pH}=3-4$ are used as fixed values. Solubility data of amorphous Th(IV) hydrous oxide at the same ionic strength $\left(0.1 \mathrm{M} \mathrm{NaClO}_{4}\right)$ and the same $\mathrm{pH}$ range are then applied to calculate the solubility product: $\log \mathrm{K}_{\mathrm{sp}}^{\prime}=-45.1$ in $0.1 \mathrm{M} \mathrm{NaClO}_{4}$, and converted to I = 0 :

$$
\log \mathrm{K}_{\mathrm{sp}}^{\mathrm{o}}=-47.2 \pm 1.0
$$

The potentiometric titration study of $[83 \mathrm{BRO} / \mathrm{ELL}]$ is the only one at $\mathrm{I}<1 \mathrm{~mol} / \mathrm{l}$. Hydrolysis constants from studies at $\mathrm{I} \geq 1 \mathrm{~mol} / 1$ would require ionic strength corrections to $\mathrm{I}=0.1$ or 0.5 $\mathrm{mol} / \mathrm{l}$. However, ion interaction coefficients for polynuclear species of high positive charge can hardily be estimated. The uncertainty of $\log \mathrm{K}_{\mathrm{sp}}^{\circ}$ is set equal to one logarithmic unit in order to cover the scattering of the experimental solubility data. This does not reflect the "true" uncertainty. Since it is not clear, whether the solubilties are primarily caused by the proposed polynuclear solution species, in particular $\mathrm{Th}_{4}(\mathrm{OH})_{12}{ }^{4+}$, or by colloids as concluded from the LIBD studies in [96KNO, 99BUN], the possible error is much greater (c.f. Table 3.4).

The experimental solubilities in the $\mathrm{pH}$ range $6-13(\log [\mathrm{Th}]=-8.2 \pm 0.3$ in 0.1 and $0.5 \mathrm{M}$ $\mathrm{NaClO}_{4}$ [89MOO], $-8.8 \pm 0.2$ in $0.1 \mathrm{M} \mathrm{NaClO}_{4}$ [87RYA/RAI] and $-8.5 \pm 0.6$ in $0.6 \mathrm{M} \mathrm{NaCl}$ and $\mathrm{KCl}[91 \mathrm{FEL} / \mathrm{RAI}])$ give the concentration of the $\mathrm{Th}(\mathrm{OH})_{4}(\mathrm{aq})$ :

$$
\log \left[\mathrm{Th}(\mathrm{OH})_{4}(\mathrm{aq})\right]=\log \mathrm{K}_{\mathrm{sp}}^{\circ}+\log \beta_{14}^{\circ}=-8.5 \pm 0.6
$$

With $\log \mathrm{K}_{\mathrm{sp}}^{\circ}=-47.2 \pm 1.0$, the formation constant of $\mathrm{Th}(\mathrm{OH})_{4}(\mathrm{aq})$ is calculated to be

$$
\log \beta^{\circ}{ }_{14}=38.7 \pm 1.2 \text {. }
$$

From $\log \beta^{\circ}{ }_{11}=11.7$ [83BRO/ELL] and $\log \beta^{\circ}{ }_{14}=38.7$ intermediate values of $\log \beta^{\circ}{ }_{12}=22.5$ \pm 1.0 and $\log \beta^{\circ}{ }_{13}=31.5 \pm 1.0$ are estimated by applying the semi-empirical electrostatic approach described in [99NEC/KIM]. According to this approach, the stepwise formation constants decrease with increasing number of $\mathrm{OH}^{-}$ligands because of the increasing electrostatic repulsion between them.

The solubility curves calcultated with these constants converted to $\mathrm{I}=0.1$ and $0.55 \mathrm{~mol} / \mathrm{l}$ are shown as solid lines in Figs. $3.5 \mathrm{a}$ and $\mathrm{b}$. The solubilities at $\mathrm{pH}<5$ in $0.5-0.6 \mathrm{M} \mathrm{NaClO}_{4}$ and $\mathrm{NaCl}$ (Fig. 3.5 b) are well fitted, when the constants $\log \mathrm{K}_{4,12}^{\prime}=-30.55$ and $\log \mathrm{K}_{6,15}^{\prime}=-34.42$ derived in $0.1 \mathrm{M} \mathrm{KNO}_{3}[83 \mathrm{BRO} / \mathrm{ELL}]$ are also used for $\mathrm{I}=0.55 \mathrm{~mol} / \mathrm{l}$, without any ionic strength correction. 


\section{Conclusions and summary of thermodynamic constants}

The hydrolysis constants of the $\mathrm{An}^{4+}$ ions and the solubility products of $\mathrm{An}(\mathrm{IV})$ oxides and hydroxides selected or evaluated in the present report are summarized in Table 4.1. The thermodynamic constants for $\mathrm{Pu}(\mathrm{IV})$ are based exclusively on experimental literature data. In the case of $\mathrm{Np}(\mathrm{IV})$ and $\mathrm{U}(\mathrm{IV})$, the lack of experimental data requires the estimation of $\log \beta^{\circ}{ }_{13}$ and $\log \beta^{\circ}{ }_{14}$ for $N p(I V)$, and $\log \beta^{\circ}{ }_{12}, \log \beta^{\circ}{ }_{13}$ and $\log \beta^{\circ}{ }_{14}$ for $U(I V)$. Because of the strong tendency to form polynuclear and colloidal species and the relative high solubility at low $\mathrm{pH}$, it is not yet possible to select unambiguous thermodynamic data for Th(IV). In order to describe the solubility of amorphous Th(IV) precipitates, a set of constants is evaluated, which includes formation constants for the polynuclear species $\mathrm{Th}_{4}(\mathrm{OH})_{12}{ }^{4+}$ and $\mathrm{Th}_{6}(\mathrm{OH})_{15}{ }^{9+}$ proposed in potentiometric titration studies. There is no experimental evidence for the formation of anionic hydrolysis species $\mathrm{An}(\mathrm{OH})_{5}{ }^{-}$, which would cause increasing solubilities at high $\mathrm{pH}$. The upper limits for $\log \beta^{\circ}{ }_{15}$ given in Table 4.1 are derived from the solubility data shown in Figs. 3.1 - 3.5.

Table 4.1. Selected thermodynamic constants for An(IV) hydrolysis species, solid oxides and hydroxides at $25^{\circ} \mathrm{C}$

\begin{tabular}{|c|c|c|c|c|}
\hline & Th(IV) & $\mathrm{U}(\mathrm{IV})$ & $\mathrm{Np}(\mathrm{IV})$ & $\mathrm{Pu}(\mathrm{IV})$ \\
\hline \multicolumn{5}{|l|}{$\log \mathrm{K}_{\mathrm{sp}}^{\circ}$} \\
\hline $\begin{array}{l}\mathrm{An}(\mathrm{OH})_{4}(\mathrm{am}) / \\
\mathrm{AnO}_{2} \cdot \mathrm{xH}_{2} \mathrm{O}(\mathrm{am})\end{array}$ & $-47.2 \pm 1.0$ & $-55.2 \pm 1.0$ & $-56.7 \pm 0.5$ & $-58.5 \pm 1.1$ \\
\hline $\mathrm{AnO}_{2}(\mathrm{cr})$ & $-54.2 \pm 1.3$ & $-60.86 \pm 0.36$ & $-63.7 \pm 1.8$ & $-64.0 \pm 1.2$ \\
\hline $\log \beta_{11}^{\circ}$ & 11.7 & $13.6 \pm 0.2$ & $14.5 \pm 0.2$ & $14.6 \pm 0.2$ \\
\hline $\log \beta_{12}^{\circ}$ & $(22.5 \pm 1.0)^{a)}$ & $(27.5 \pm 1.0)^{a)}$ & $28.2 \pm 0.3$ & $28.6 \pm 0.3$ \\
\hline $\log \beta^{\circ}{ }_{13}$ & $(31.5 \pm 1.0)^{a)}$ & $(38.2 \pm 1.0)^{a)}$ & $(39.2 \pm 1.0)^{a)}$ & $39.7 \pm 0.4$ \\
\hline $\log \beta_{14}^{\circ}$ & $38.7 \pm 1.2^{b)}$ & $\begin{array}{c}(45.7 \pm 1.0)^{a)} \\
46.7 \pm 1.4^{b)}\end{array}$ & $\begin{array}{c}(47.2 \pm 1.0)^{a)} \\
47.7 \pm 1.1\end{array}$ & $47.5 \pm 0.5$ \\
\hline $\log \beta_{15}^{\circ}$ & $<39.5$ & $<48.0$ & $<48.5$ & $<49.5$ \\
\hline $\log \beta_{4,12}^{\prime}$ & $135.0^{\mathrm{c})}$ & & & \\
\hline $\log \beta_{6,15}^{\prime}$ & $172.5^{c)}$ & & & \\
\hline $\log \left[\mathrm{An}(\mathrm{OH})_{4}(\mathrm{aq})\right]$ & $-8.5 \pm 0.6$ & $-8.5 \pm 1.0$ & $-9.0 \pm 1.0$ & $-11.0 \pm 1.1$ \\
\hline
\end{tabular}


The solubilities in acidic solutions depend strongly on the pretreatment and alteration of the solid phase. An opposite behaviour has been observed in neutral and alkaline solutions, particularly in solubility studies with $\mathrm{Th}(\mathrm{IV})$ and $\mathrm{U}(\mathrm{IV})$. In the range $\mathrm{pH}=6-13$, the measured solubilities are independent of whether $\mathrm{AnO}_{2}$ (cr) or $\mathrm{AnO}_{2} \cdot \mathrm{xH}_{2} \mathrm{O}(\mathrm{am}$ ) is used as the initial solid phase, although the solubility products of the crystalline An(IV) dioxides are about $6 \pm 1$ orders of magnitude lower than those of the corresponding amorphous hydroxides or hydrous oxides. Consequently, in neutral and alkaline solutions, where $\operatorname{An}(\mathrm{OH})_{4}(\mathrm{aq})$ is the predominant aqueous species, the measured solubilities must refer to a solid phase of comparable thermodynamic stability. Since the $\mathrm{pH}$-independent solubilities in this range correspond to the sums $\left(\log \mathrm{K}^{\circ}{ }_{\text {sp }}\left(\mathrm{AnO}_{2} \cdot \mathrm{xH}_{2} \mathrm{O}(\mathrm{am})\right)+\log \beta^{\circ}{ }_{14}\right)$, it is assumed that a bulk crystalline dioxide must be covered with an amorphous surface layer. This solubility limiting surface layer might be formed according to the following dissolution-precipitation scheme:

(1) $\mathrm{AnO}_{2}(\mathrm{cr})+2 \mathrm{H}_{2} \mathrm{O} \Leftrightarrow \mathrm{An}^{4+}+4 \mathrm{OH}^{-}$

(2) $\mathrm{An}^{4+}+4 \mathrm{OH}^{-} \Leftrightarrow \mathrm{An}(\mathrm{OH})_{4}(\mathrm{aq})$

(3) $\mathrm{An}(\mathrm{OH})_{4}(\mathrm{aq}) \Leftrightarrow \mathrm{An}(\mathrm{OH})_{4}(\mathrm{am})$

(4) $\mathrm{An}(\mathrm{OH})_{4}(\mathrm{am})<=\mathrm{AnO}_{2} \cdot \mathrm{xH}_{2} \mathrm{O}(\mathrm{am})+(2-\mathrm{x}) \mathrm{H}_{2} \mathrm{O}$

Although this hypothetical reaction scheme is not yet ascertained by independent analytical methods, it is more likely than any other interpretation. Solubility data measured with crystalline $\mathrm{PuO}_{2}(\mathrm{cr}), \mathrm{UO}_{2}(\mathrm{cr})$ and $\mathrm{ThO}_{2}(\mathrm{cr})$ at $\mathrm{pH}=0-3$ were generally much lower than corresponding data with amorphous precipitates, even after equilibration periods of several months or years. Nevertheless, it appears questionable, whether step (1) is reversible, i.e. whether $\mathrm{AnO}_{2}$ (cr) is the solubility limiting solid phase in acidic solutions, or whether the formation of an amorphous, more soluble surface layer is merely hindered by slow dissolution kinetics. 


\section{References}

[49KAS]

Kasha, M.;

Reactions between Plutonium Ions in Perchloric Acid Solution: Rates, Mechanism, and Equilibria, in: The Transuranium Elements, Research Papers (Eds.: G.T. Seaborg, J.J. Katz, W.M. Manning), p. 295, McGraw-Hill, New York, 1949

[50KRA/NEL]

Kraus, K.A., Nelson, F.;

Hydrolytic Behavior of Metal Ions. I. The Acid Constants of Uranium(IV) and

Plutonium(IV); J. Am. Chem. Soc. 72, 3901 (1950)

\section{[51RAB/LEM]}

Rabideau, S.W., Lemons, J.F.,

The Potential of the Pu(III)-Pu(IV) Couple and the Equilibrium Constants for Some

Complex Ions of Pu(IV); J. Am. Chem. Soc. 73, 2895 (1951)

[56HIE]

Hietanen, S.;

Studies on the Hydrolysis of Metal Ions: 17. The Hydrolysis of the $\mathrm{U}^{4+}$ Ion;

Acta Chem. Scand. 10, 1531 (1956)

\section{[57GAY/LEI]}

Gayer, K.H., Leider, H.;

The Solubility of Uranium(IV) Hydroxide in Solutions of Sodium Hydroxide and

Perchloric Acid at $25^{\circ} \mathrm{C}$; Can. J. Chem. Scand. 35, 5 (1957)

[57RAB]

Rabideau, S.W.;

The Hydrolysis of Pu(IV); J. Am. Chem. Soc. 79, 3675 (1957)

\section{[59SUL/HIN]}

Sullivan, J.C., Hindman, J.C.;

The Hydrolysis of Neptunium(IV); J. Phys. Chem. 63, 1332 (1959)

[60RAB/KLI]

Rabideau, S., Kline, R.J.;

A Spectrophotometric Study of the Hydrolysis of Plutonium(IV);

J. Phys. Chem. 64, 680 (1960)

[64NAB/KUD]

Nabivanets, B.I., Kudritskaya, L.N.;

Hydroxocomplexes of Thorium(IV); Ukr. Khim. Zh. 30, 891 (1964)

\section{[65BAE/MEY]}

Baes, C.F.,Jr., Meyer, N.J., Roberts, C.E.;

The Hydrolysis of Thorium(IV) at 0 and $95^{\circ}$; Inorg. Chem. 4, 518 (1965) 
[65PER]

Pérez-Bustamente, J.A.;

Solubility Product of Tetravalent Plutonium Hydroxide and Study of the Amphoteric

Character of Hexavalent Plutonium Hydroxide; Radiochim. Acta 4, 67 (1965)

[68CLE]

Cleveland, J.M.;

Sulfamate Complexes of Plutonium(IV); Inorg. Chem. 7, 874 (1968)

[69MET/GUI]

Metivier, H., Guillaumont, R.;

Contribution a l'etude de l'hydrolyse du Plutonium tetravalent;

Radiochem. Radioanal. Lett. 1, 209 (1969)

[70PAU]

Paul, M., Th.;

Die Komplexierung vierwertiger Actiniden mit Pyridin- und $\alpha$-Aminopolykarbonsäuren;

Report KFK 1210, Kernforschungszentrum Karlsruhe, Germany, 1970

[72FUG]

Fuger, J.,

Thermodynamic Properties of Simple Actinide Compounds,.

MTP Int. Rev. Sci, Ser.1, 7, 157 (1972)

[72MET/GUI]

Metivier, H., Guillaumont, R.;

Hydrolyse du Plutonium tetravalent; Radiochem. Radioanal. Lett. 10, 27 (1972)

[73MET]

Metivier, H.;

Contribution a l'etude de l'hydrolyse du Plutonium tetravalent et de sa complexation par des acides d'interet biologique; Rapport CEA-R-4477, Gif-sur-Yvette, France, 1973

[76BAE/MES]

Baes, C.F.,Jr., Mesmer, R.E.;

The Hydrolysis of Cations, Wiley-Intersciece, New York, 1976

[76FUG/OET]

Fuger, J., Oetting, F.L.;

The Chemical Thermodynamics of Actinide Elements and Compounds Part 2.

The Actinide Aqueous Ions;

IAEA, Int. Atomic Energy Agency, Vienna, Austria, 1976

[76OET/RAN]

Fuger, J., Oetting, F.L., Rand, M.H., Ackermann, R.J.;

The Chemical Thermodynamics of Actinide Elements and Compounds Part 1.

The Actinide Elements;

IAEA, Int. Atomic Energy Agency, Vienna, Austria, 1976 


\section{[76SHA]}

Shannon, R.D.;

Revised Effective Ionic Radii and Systematic Studies of Interatomic Distances in Halides and Chalcogenides; Acta Cryst A32, 751 (1976)

\section{[77DUP/GUI]}

Duplessis, J., Guillaumont, R.,

Hydrolyse du Neptunium tetravalent; Radiochem. Radioanal. Lett. 31, 293 (1977)

\section{[78FED/PER]}

Fedoseev, A..M., Peretrukhin, V.F., Orlova, M.M., Krot, N.N.;

Spectrophotometric Study of the Hydrolysis of Tetravalent Neptunium in Aqueous

Organic Solutions; Soviet Radiochem. 20, 686 (1978)

[80CIA]

Ciavatta, L.;

The Specific Interaction Theory in Evaluating Ionic Equilibria;

Ann. Chim. (Rome), 551 (1980)

\section{[80HAR/WEA]}

Harvie, C.F., Weare, J.H.;

The prediction of mineral solubilities in natural waters: The $\mathrm{Na}-\mathrm{K}-\mathrm{Mg}-\mathrm{Ca}-\mathrm{Cl}-\mathrm{SO}_{4}-\mathrm{H}_{2} \mathrm{O}$ systemfrom zero to high concentrations at $25^{\circ} \mathrm{C}$;

Geochim. Cosmochim. Acta 44, 981 (1980)

[80RAI/SER]

Rai, D., Serne, R.J., Moore, D.A.,

Solubility of Plutonium Compounds and Their Behavior in Soils,

Soil Sci. Am. J. 44, 490 (1980)

[82RAI/RYA]

Rai, D., Ryan, J.L.;

Crystallinity and Solubility of Pu(IV) Oxide and Hydrous Oxide in Aged Aqueous

Suspensions; Radiochim. Acta 30, 213 (1982)

\section{[82WAG/EVA]}

Wagmann, D.D., Evans, W.H., Parker, V.B., Schumm. R.H., Halow, I., Bailey, S.M.,

Churney, K.L., Nuttal, R.H.;

The NBS tables of chemical thermodynamic properties;

J. Phys. Chem. Ref. Data 11, Suppl.2 (1982)

\section{[83BRO/ELL]}

Brown, P.L., Ellis, J., Sylva, R.N.;

The Hydrolysis of Metal Ions, Part 5. Thorium(IV);

J. Chem. Soc. Dalton Trans. 31 (1983)

\section{[83CHO]}

Choppin, G.R.;

Solution Chemistry of the Actinides; Radiochim. Acta 32, 43 (1983) 
[83STR/RAI]

Strickert, R.G., Rai, D., Fulton, R.W.;

Effect of Aging on the Solubility and Crystallinity of $\mathrm{Np}$ (IV) Hydrous Oxide,

ACS Symp. Ser. 246, 135 (1983)

[84GRE/LIE]

Greiling, H.-D., Lieser, K.H.;

Properties of $\mathrm{ThO}_{2}, \mathrm{UO}_{2}$ and $\mathrm{PuO}_{2}$ as Function of Pretreatment and their Dissolution in

$\mathrm{HNO}_{3}$, Radiochim. Acta 35, 79 (1984)

[84HAR/MøL]

Harvie, C.F., Møller, N., Weare, J.H.;

The prediction of mineral solubilities in natural waters: The Na-K-Mg-Ca-H-Cl-SO $-\mathrm{C}-\mathrm{OH}-$ $\mathrm{HCO}_{3}-\mathrm{CO}_{2}-\mathrm{H}_{2} \mathrm{O}$ System to high ionic strengths at $25^{\circ} \mathrm{C}$;

Geochim. Cosmochim. Acta 48, 723 (1984)

[84NAK/ZIM]

Nakashima, T., Zimmer, E.;

Hydrolysis of $\mathrm{Th}\left(\mathrm{NO}_{3}\right)_{4}$ and its Extractability by TBP; Radiochim. Acta 37, 165 (1984)

[84RAI]

Rai, D.;

Solubility Product of $\mathrm{Pu}(\mathrm{IV})$ Hydrous Oxide and Equilibrium Constants of $\mathrm{Pu}(\mathrm{IV}) / \mathrm{Pu}(\mathrm{V})$, $\mathrm{Pu}(\mathrm{IV}) / \mathrm{Pu}(\mathrm{VI})$, and $\mathrm{Pu}(\mathrm{V}) / \mathrm{Pu}(\mathrm{VI})$ Couples; Radiochim. Acta 35, 97 (1984)

[85MAR]

Marcus, Y.;

Ion Solvation; Wiley-Interscience, Chichester, 1985

[85PAR/POH]

Parks, G.A., Pohl, D.C.;

Hydrothermal solubility of uraninite; Report DOE/ER 12016-1, Stanford, 1985

Geochim. Cosmochim. Acta 52, 863 (1988)

[85RAI/RYA]

Rai, D., Ryan, J.L.;

Neptunium(IV) Hydrous Oxide Solubility under Reducing and Carbonate Conditions;

Inorg. Chem. 24, 247 (1985)

[86LIE/KIM]

Lierse, Ch., Kim, J.I.,

Chemisches Verhalten von Plutonium in natürlichen aquatischen Systemen: Hydrolyse,

Carbonatkomplexierung und Redoxreaktionen;

Report RCM 02286, Inst. für Radiochemie, Technische Universität München, 1986

\section{[87BRU/CAS]}

Bruno, J., Casas,I., Lagerman, B., Munoz, M.;

The Determination of the Solubility of amorphous $\mathrm{UO}_{2}(\mathrm{~s})$ and the Mononuclear

Hydrolysis Constants of Uranium(IV) at $25^{\circ} \mathrm{C}$;

Mat. Res. Soc. Symp. Proc. 84, 153 (1987) 
[87RAI/SWA]

Rai, D., Swanson, J.L., Ryan, J.L.;

Solubility of $\mathrm{NpO}_{2} \cdot \mathrm{x} \mathrm{H}_{2} \mathrm{O}$ (s) in the Presence of $\mathrm{Cu}$ (I) / Cu(II) Redox Buffer;

Radiochim. Acta 42, 35 (1987)

[87RYA/RAI]

Ryan, J.L., Rai, D.;

Thorium(IV) Hydrous Oxide Solubility; Inorg. Chem. 26, 4140 (1987)

[89KIM/KAN]

Kim, J.I., Kanellakopulos, B.;

Solubility Products of Plutonium(IV) Oxide and Hydroxide;

Radiochim. Acta 48, 145 (1989)

[89MOO]

Moon, H.C.;

Equilibrium Ultrafiltration of Hydrolized Thorium(IV) Solutions,

Bull. Korean Chem. Soc. 10, 270 (1989)

[90PAZ/KUD]

Pazukhin, E.M., Kudryavtsev, E.G.;

Stability Constants of Hydrolyzed Forms of $\mathrm{Pu}(\mathrm{IV})$ and Solubility Product of its

Hydroxide; Soviet Radiochem. 32, 318 (1990)

[90RAI/FEL]

Rai, D., Felmy, A.R., Ryan, J.L.;

Uranium(IV) Hydrolysis and the Solubility Product of $\mathrm{UO}_{2} \cdot \mathrm{xH}_{2} \mathrm{O}(\mathrm{am})$,

Inorg. Chem. 29, 260 (1990)

[91CHO/MAT]

Choppin, G.R., Mathur, J.N.;

Hydrolysis of Actinyl(VI) Cations; Radiochim. Acta 52/53, 25 (1991)

[91FEL/RAI]

Felmy, A.R., Rai, D., Mason, M.J.;

The Solubility of Hydrous Thorium(IV) Oxide in Chloride Media: Development of an

Aqueous Ion-Interaction Model; Radiochim. Acta 55, 177 (1991)

[91GRE/LAG]

Grenthe, I., Lagermann, B.;

Studies on Metal Carbonate Equilibria. 23. Complex Formation in the

$\mathrm{Th}(\mathrm{IV})-\mathrm{H}_{2} \mathrm{O}-\mathrm{CO}_{2}$ (g) System; Acta Chem. Scand. 45, 231 (1991)

[91PIT]

Pitzer, K. S.,

Activity Coefficients in Electrolyte Solutions, Chap.3,

CRC Press, Boca Raton, Florida, 1991 


\section{[92CAP/VIT]}

Capdevila, H., Vitorge, P., Giffaut, E.;

Stability of Pentavalent Plutonium. Spectrophotometric Study of $\mathrm{PuO}_{2}^{+}$and $\mathrm{Pu}^{4+}$

Disproportionation in Perchloric Media; Radiochim. Acta 58/59, 45 (1992)

[92FUG]

Fuger, J.;

Thermodynamic Properties of Actinide Aqueous Species Relevant to Geochemical

Problems; Radiochim. Acta. 58/59, 81 (1992)

\section{[92FUG/KHO]}

Fuger, J., Khodakovsky, I.L., Sergeyeva, E.I., Medvedev, V.A., Navratil, J.D.,

The Chemical Thermodynamics of Actinide Elements and Compounds, Part 12.

The Actinide Aqueous Inorganic Complexes;

IAEA International Atomic Energy Agency, Vienna, Austria, 1992

\section{[92GRE/FUG]}

Grenthe, I., Fuger, J., Konings, R.J.M.., Lemire, R.J., Muller, A.B., Nguyen-Trung, C.

Wanner, H. (OECD, NEA-TDB); Chemical Thermodynamics Vol. 1. Chemical

Thermodynamics of Uranium; Elsevier Science Publ., North-Holland, Amsterdam, 1992

\section{[93ERI/NDA]}

Eriksen, T.E., Ndalamba, P., Cui, D., Bruno, J., Caceci, M., Spahiu, K.;

Solubility of the Redox-Sensitive Radionuclides ${ }^{99} \mathrm{Tc}$ and ${ }^{237} \mathrm{~Np}$ Under Reducing

Conditions in Neutral to Alkaline Solutions. Effect of Carbonate ;

SKB TechnicalReport, TR 93-18, Stockholm, 1993

\section{[94CHO/RIZ]}

Choppin, G.R., Rizkalla, E.N.;

Solution Chemistry of Actinides and Lanthanides; in: Handbook on the Physics and Chemistry of Rare Earths (Eds.: K.A. Gschneidner Jr, L. Eyring), Vol.18, Chap.128, 559, North Holland, Amsterdam, 1994

\section{[94FAN/KIM]}

Fanghänel, Th., Kim, J.I, Paviet, P., Klenze, R., Hauser, W.;

Thermodynamics of Radioactive Trace Elements in Concentrated Electrolyte Solutions:

Hydrolysis of $\mathrm{Cm}^{3+}$ in NaCl-Solutions; Radiochim. Acta 66/67, 81 (1994)

\section{[94ÖST/BRU]}

Östhols, E., Bruno, J., Grenthe, I.;

On the influence of carbonate on mineral dissolution: III. The solubility of micro-

crystalline $\mathrm{ThO}_{2}$ in $\mathrm{CO}_{2}-\mathrm{H}_{2} \mathrm{O}$ media; Geochim. Cosmochim. Acta 58, 613 (1994)

\section{[95FAN/NEC]}

Fanghänel, Th., Neck, V., Kim, J.I.;

Thermodynamics of Neptunium(V) in Concentrated Salt Solutions. II. Ion Interaction

(Pitzer) Parameters for Np(V) Hydrolysis Species and Carbonate Complexes,

Radiochim. Acta 69, 169 (1995) 
[95SIL/BID]

Silva, R.J., Bidoglio, G., Rand, M.H., Robouch, P., Wanner, H., Puigdomenech, I..

(OECD, NEA-TDB); Chemical Thermodynamics Vol. 2., Chemical Thermodynamics of Americium; Elsevier Science Publ., North-Holland, Amsterdam, 1995

[95YAJ/KAW]

Yajima, T., Kawamura, Y., Ueta, S.;

Uranium(IV) Solubility and Hydrolysis Constants under Reduced Conditions;

Mat. Res. Soc. Symp. Proc. 353, 1137 (1995)

[96FAN/NEC]

Fanghänel, Th., Neck, V., Kim, J.I.;

The Ion Product of $\mathrm{H}_{2} \mathrm{O}$, Dissociation Constants of $\mathrm{H}_{2} \mathrm{CO}_{3}$ and Pitzer parameters in the System $\mathrm{Na}^{+} / \mathrm{H}^{+} / \mathrm{OH}^{-} / \mathrm{HCO}_{3}-/ \mathrm{CO}_{3}{ }^{2-} / \mathrm{ClO}_{4}^{-} / \mathrm{H}_{2} \mathrm{O}$ at $25^{\circ} \mathrm{C}$;

J. Solution Chem. 25, 327 (1996)

[96KNO]

Knopp, R.;

Laserinduzierte Breakdowndetektion zur Charakterisierung und Quantifizierung aquatischer Kolloide; Thesis, Technische Universität München, 1996

Knopp, R., Scherbaum, F.J., Kim, J.I.; Report RCM 00696, Institut für Radiochemie, Technische Universität München, 1996

[96NAK/YAM]

Nakayama, S., Yamaguchi, T., Sekine, K.;

Solubility of $\mathrm{Np}(\mathrm{IV})$ Hydrous Oxide in Aqueous Solutions;

Radiochim. Acta 74, 15 (1996)

[96RUN/NEU]

Runde, W., Neu, M.P., Clark, D.L.;

Neptunium(V) hydrolysis and carbonate complexation: Experimental and predicted neptunyl solubility in concentrated $\mathrm{NaCl}$ using the Pitzer approach;

Geochim. Cosmochim. Acta 60, 2065 (1996)

[97GRE/PUI]

Grenthe, I., Puigdomenech, I.. (OECD, NEA),

Modelling in Aquatic Chemistry; OECD, Nuclear Energy Agency, Paris, 1997

[97KÖN/FAN]

Könnecke, Th., Fanghänel, Th., Kim, J.I.,

Thermodynamics of Trivalent Actinides in Concentrated Electrolyte Solutions:

Modelling the Chloride Complexation of Cm(III); Radiochim. Acta 76, 131 (1997)

[97PAS/CZE]

Pashalidis, I., Czerwinski, K.R., Fanghänel, Th., Kim, J.I.;

Solid-Liquid Phase Equilibria of $\mathrm{Pu}(\mathrm{VI})$ and U(VI) in Aqueous Carbonate Systems.

Determination of Stability Constants; Radiochim. Acta 76, 55 (1997) 
[97RAI/FEL]

Rai, D., Felmy, A.R., Sterner, S.M., Moore, D.A., Mason, M.J., Novak, C.F.;

The Solubility of Th(IV) and U(IV) Hydrous Oxides in Concentrated $\mathrm{NaCl}$ and $\mathrm{MgCl}_{2}$

Solutions; Radiochim. Acta 79, 239 (1997)

[98CAP/VIT]

Capdevila, H., Vitorge, P.;

Solubility Product of $\mathrm{Pu}(\mathrm{OH})_{4}(\mathrm{am})$; Radiochim. Acta 82, 11 (1998)

[98NEC]

Neck, V.;

Solubility and Hydrolysis of Tetravalent Actinides;

Statusseminar INE, Forschungszentrum Karlsruhe, December 1998

[98NEC/FAN]

Neck, V., Fanghänel, Th., Kim, J.I.;

Aquatische Chemie und thermodynamische Modellierung von trivalenten Actiniden;

Report FZKA 6110, Forschungszentrum Karlsruhe, 1998

[98RAI/FEL]

Rai, D., Felmy, A.R., Hess, N.J., Moore, D.A., Yui, M.;

A Thermodynamic Model for the Solubility of $\mathrm{UO}_{2}(\mathrm{am})$ in the Aqueous $\mathrm{K}^{+}-\mathrm{Na}^{+}-\mathrm{HCO}_{3}{ }^{-}-$

$\mathrm{CO}_{3}{ }^{2-}-\mathrm{OH}^{-}-\mathrm{H}_{2} \mathrm{O}$ System; Radiochim. Acta 82, 17 (1998)

[99BUN]

Bundschuh, T.;

Entwicklung und Anwendung der Laser-induzierten Breakdown-Detektion zur

Quantifizierung aquatischer Kolloide und Actinidenkolloide;

Thesis, Inst. für Radiochemie, Technische Universität München, 1999

Bundschuh, T., Kim, J.I.; Report FZKA 6273, Forschungszentrum Karlsruhe, 1999

[99GRA/MÜL]

Grambow, B., Müller, R.;

Solids, Colloids and Hydrolysis of U(IV) in Chloride Media;

INE, Forschungszentrum Karlsruhe (private communication), to be published

[99NEC/KIM]

Neck, V., Kim, J.I.;

An Electrostatic Approach for the Prediction of Actinide Complexation Constants;

Internat. Conference Migration ‘99, Lake Tahoe, USA, 1999

Report FZKA, in preparation 